\title{
Substrates for Efficient Fluorometric Screening Employing the NAD-Dependent Sirtuin 5 Lysine Deacylase (KDAC) Enzyme
}

\author{
Madsen, Andreas Stahl; Olsen, Christian Adam
}

Published in:

Journal of Medicinal Chemistry

Link to article, DOI:

10.1021/jm300526r

Publication date:

2012

Document Version

Publisher's PDF, also known as Version of record

Link back to DTU Orbit

Citation (APA):

Madsen, A. S., \& Olsen, C. A. (2012). Substrates for Efficient Fluorometric Screening Employing the NAD-

Dependent Sirtuin 5 Lysine Deacylase (KDAC) Enzyme. Journal of Medicinal Chemistry, 55(11), 5582-5590.

https://doi.org/10.1021/jm300526r

\section{General rights}

Copyright and moral rights for the publications made accessible in the public portal are retained by the authors and/or other copyright owners and it is a condition of accessing publications that users recognise and abide by the legal requirements associated with these rights.

- Users may download and print one copy of any publication from the public portal for the purpose of private study or research.

- You may not further distribute the material or use it for any profit-making activity or commercial gain

- You may freely distribute the URL identifying the publication in the public portal 


\title{
Journal of

\section{Substrates for Efficient Fluorometric Screening Employing the NAD- Dependent Sirtuin 5 Lysine Deacylase (KDAC) Enzyme}

\author{
Andreas S. Madsen and Christian A. Olsen* \\ Department of Chemistry, Technical University of Denmark, Kemitorvet 207, DK-2800, Kongens Lyngby, Denmark \\ Supporting Information
}

ABSTRACT: The class III lysine deacylases (KDACs), also known as the sirtuins, have emerged as interesting drug targets for therapeutic intervention in a variety of diseases. To gain a deeper understanding of the processes affected by sirtuins, the development of selective small molecule modulators of individual isozymes has been a longstanding goal. Essential for the discovery of novel modulators, however, are good screening protocols and mechanistic insights with regard to the

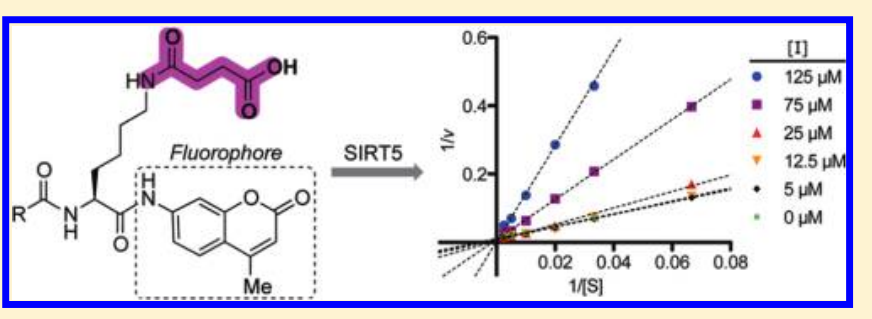
targets in question. We therefore evaluated the activities of the seven human sirtuin hydrolases against a panel of fluorogenic substrates. Both commonly used, commercially available substrates and novel chemotypes designed to address recent developments in the field of lysine post-translational modification were evaluated. Our investigations led to the discovery of two new fluorogenic $\varepsilon$ - $N$-succinyllysine-containing substrates that enable highly efficient and enzyme-economical screening employing sirtuin 5 (SIRT5). Furthermore, optimized protocols for facile kinetic investigations were developed, which should be valuable for enzyme kinetic investigations. Finally, these protocols were applied to a kinetic analysis of the inhibition of SIRT5 by suramin, a potent sirtuin inhibitor previously shown by X-ray crystallography to bind the substrate pocket of the human SIRT5 KDAC enzyme.

\section{INTRODUCTION}

The sirtuins, silent information regulator 2 (Sir2) enzymes, are a family of NAD-dependent KDACs comprising seven human isoforms (SIRT1-7). ${ }^{1-4}$ These enzymes have been linked to a variety of phenotypes and are therefore considered targets for therapeutic intervention in a broad spectrum of diseases, including various cancers, diabetes, cardiovascular disease, and neurodegeneration. ${ }^{5-8}$ The human genome encodes for a total of 18 different KDACs, 11 of which are $\mathrm{Zn}^{2+}$-dependent isoforms (classes I, II, and IV), while the sirtuins constitute the class III KDACs (Figure 1a). ${ }^{1,2}$ Contrary to the $\mathrm{Zn}^{2+}$ dependent isozymes, the sirtuins utilize $\mathrm{NAD}$ as a cofactor in a deacylation event that has been studied mechanistically ${ }^{9-12}$ as well as supported by several X-ray cocrystal structures with substrates and/or cofactor bound to the enzyme ${ }^{13-17}$ (see Figure $1 \mathrm{~b}$ for overall reaction). Only sirtuins $1-3$ and 5 have been shown to harbor robust deacetylase activity, while sirtuins 6 and 7 were significantly less active and SIRT4 showed no activity. ${ }^{18,19}$ Sirtuin 4 has been shown to facilitate ADPribosylation ${ }^{20}$ and has therefore been suggested to be an ADPribosyl transferase enzyme rather than a deacetylase. Moreover, SIRT5 was recently shown to be a potent demalonylase and desuccinylase of lysine residues in mitochondrial proteins. ${ }^{21}$ The precise roles of the individual $\mathrm{KDAC}$ isoforms in cellular function are not yet fully understood, however, and new tools for accurate and efficient profiling of their enzymatic activity are therefore highly desirable. Furthermore, development of protocols for high-throughput screening efforts aimed at the discovery of new inhibitor candidates is an important objective.
In light of the recent discovery of novel post-translational acylations of lysine $\varepsilon$-amino groups, ${ }^{22}$ we envisioned that performance of a systematic screening of the specificities of the complete panel of recombinant human sirtuins $1-7$ against a series of fluorogenic substrates accommodating variations in both peptide sequence and identity of the $\varepsilon$ - $N$-acyl group might yield interesting new tools for some of these enzymes.

\section{RESULTS AND DISCUSSION}

Substrate Collection. For the profiling, we selected the collection of substrates shown in Scheme 1a. Fluorogenic peptide fragments 1-3 (based on p53 fragments), 5a (based on a histone 4 fragment), and $\mathbf{6 a}$ are commercially available substrates used for assays employing the various KDAC enzyme isoforms. Substrate 4 was designed based on part of the amino acid sequence of histone 3 (amino acids 6-9), and it was included in our series because of work demonstrating activity of SIRT6 against a H3K9Ac peptide in vitro ${ }^{23}$ (see Supporting Information Scheme S1 for synthetic route). Substrates $\mathbf{5 b}, \mathbf{5 c}$, $\mathbf{6 b}$, and $\mathbf{6 c}$ were designed and included in our panel to address the recently discovered activities of SIRT5 against $\varepsilon$-Nsuccinyllysine (Ksuc) and $\varepsilon$ - $N$-malonyllysine (Kma) containing substrates. Finally, we included a recently developed substrate for efficient profiling of class IIa KDACs (5d), ${ }^{24}$ as well as a crotonylated peptide $(\mathbf{5 e})$ to address the recent discovery of $\varepsilon$ $\mathrm{N}$-crotonyllysine (Kcr) residues in histone tails. ${ }^{25}$

Received: April 13, 2012

Published: May 15, 2012 


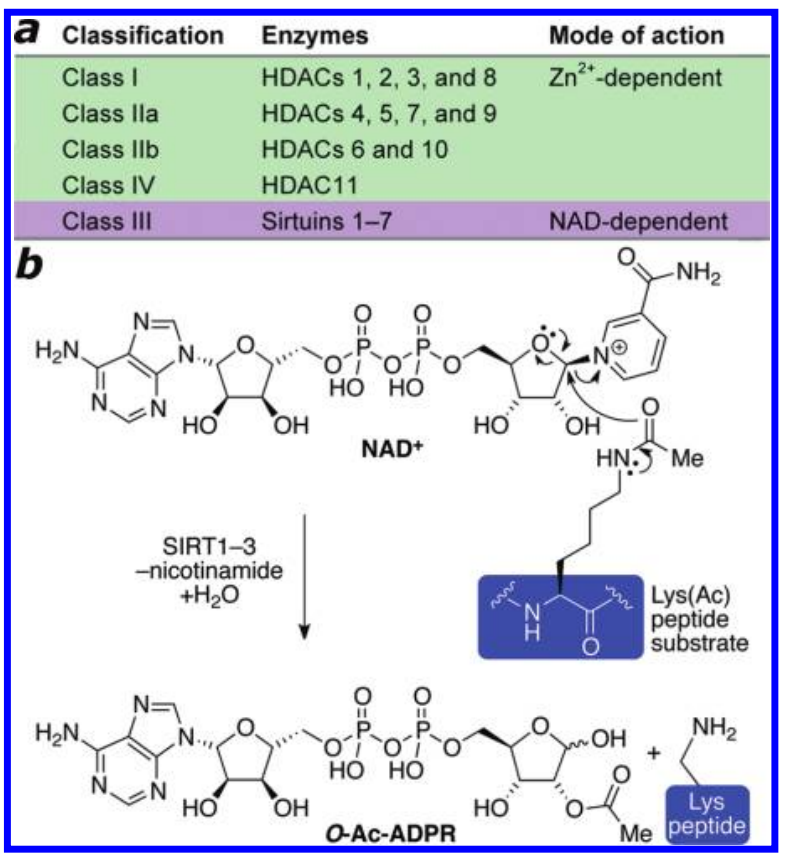

Figure 1. (a) Sequence-based classification of the human lysine deacetylases. (b) Proposed overall mechanism of the NAD-dependent lysine deacetylation of the active sirtuins $1-3$. Complete details can be found in the referenced literature. ${ }^{9-12,19}$

The synthesis of substrate $\mathbf{5} \mathbf{d}$ has been reported previously; ${ }^{24}$ however, we were interested in devising an efficient strategy that would deliver $\mathbf{5 a - e}$ in a convergent manner from inexpensive starting materials. As several attempts to introduce the AMC fluorophore at a late-stage failed, we applied the protocol of Jung and co-workers ${ }^{26}$ followed by mild Fmoc removal to prepare intermediate 8 in high yield. Subsequent standard peptide coupling using DIC and HOBt as coupling reagents and Boc group removal furnished peptide 10, which could be readily functionalized to give substrates $\mathbf{5 a - e}$ (Scheme $1 \mathrm{~b}$ ). The intermediate $\mathbf{8}$ was also used for preparation of substrates $\mathbf{6 b}$ and $\mathbf{6 c}$ (Supporting Information Scheme S2).

Substrate Profiling with SIRT1-7. For comparison we first tested for deacylation using $1 \mu \mathrm{g}$ of enzyme per reaction. The deacylations were allowed to proceed for $1 \mathrm{~h}$ before adding trypsin "developer" to release the fluorophore of deacylated substrate molecules and thereby obtain end point assay readings (see Supporting Information Figure S1 for schematic representation of the assay). Not surprisingly, on the basis of the literature, ${ }^{19}$ SIRT1-3 generally exhibited good activities toward the acetylated (Kac) substrates, whereas no measurable activities were observed for sirtuins 4, 6, and 7 (Figure 2). Sirtuin 5 exhibited poor activity against the Kac substrates in our collection, with only a poor signal-to-background ratio observed against substrate 2, which is somewhat surprising because SIRT5 has been classified as an active deacetylase enzyme. ${ }^{19}$ This, however, agrees with more recent investigations reporting low affinity for Kac substrates with SIRT5. ${ }^{21}$ On the other hand, SIRT5 exhibited very efficient desuccinylase activity with substrate $\mathbf{5 b}$, which is also in agreement with recent contributions in the literature using nonfluorogenic substrates. ${ }^{21,27}$ Unfortunately, substrate 4, which was designed in the hopes of achieving activity of SIRT6, did not furnish a measurable signal under the applied conditions. This indicates that more elaborate H3K9Ac-containing fragments are necessary in order to obtain SIRT6 deacetylase activity, as the reported activity was observed with a $\sim 2700$ Da H3 peptide. $^{20}$ In addition, the reported activity was obtained with $>4$ times the amount of enzyme used in the present study, which would be considered a prohibitively large amount of enzyme for screening purposes.

The activities of sirtuins $1-3$ and 5 were then measured against substrates $\mathbf{5 a}-\mathbf{c}$ and $\mathbf{6 a}-\mathbf{c}$, which confirmed a selective demalonylase and desuccinylase activity of SIRT5, while SIRT1-3 showed deacetylase activity exclusively (Figure 3 ).

The deacetylation reactions catalyzed by SIRT1 were performed with two different commercially available preparations of the enzyme to test whether this would influence the substrate specificity. Thus, the six acetylated substrates were treated with full-length SIRT1 enzyme ${ }^{28}$ or a truncated SIRT1GST fusion protein, ${ }^{29}$ respectively (Supporting Information Figure S2). Under the applied conditions, the efficacies of these two different enzymes followed the same general trend but with higher activities observed for the full-length enzyme except against substrate 4 where equally good activities were observed (Supporting Information Figure S2).

Finally, the activities of SIRT1-3, SIRT5, and SIRT6 against substrates $\mathbf{5 d}$ and $\mathbf{5 e}$ were recorded under the same conditions as described vide supra. The very low activities observed against substrate $\mathbf{5 d}$ are in agreement with previous findings. ${ }^{30}$ Decrotonylase activity was investigated briefly using substrate 5e because of the very recent work showing that crotonylation of $\varepsilon$-amino groups of lysine residues should now be considered a possible post-translational modification in histone proteins. ${ }^{25}$ A weak signal was observed for SIRT1, which may warrant further investigations with more elaborate substrates in the future, while a lack of activity was observed for sirtuins 2, 3, 5, and 6 (Supporting Information Figure S3). As such, our results do not indicate that sirtuins harbor potent decrotonylase activity, albeit based on a limited data set.

Optimization of SIRT5 Desuccinylase Assays. Because of the high efficacy of SIRT5 observed against succinylated substrates $\mathbf{5 b}$ and $\mathbf{6 b}$ (Figure 3 ), we envisioned that these substrates might potentially prove useful for efficient screening of putative inhibitor compounds and decided to address these substrates in further detail. ${ }^{31}$ First, we performed titrations to determine appropriate amounts of enzyme necessary for SIRT5 screening with $\mathbf{5 b}$ or $\mathbf{6 b}$, which showed that an enzyme loading as low as $50 \mathrm{ng}$ of SIRT5 per reaction $(30 \mathrm{nM})$ was sufficient for end point readings with both substrates (Supporting Information Figure S4). Then kinetic constants were determined by measuring initial rate velocities as a function of substrate concentration and fitting the data to the Michaelis-Menten equation to give the $K_{\mathrm{m}}$ and $V_{\max }$ values as shown in Table 1 . The $k_{\text {cat }}$ values were calculated from the relationship $k_{\text {cat }}=V_{\max }[\text { enzyme }]^{-1}$, based on enzyme stock concentration and purity given by the enzyme suppliers.

The turnover numbers $\left(k_{\mathrm{cat}}\right)$ and catalytic efficiencies $\left(k_{\mathrm{cat}} K_{\mathrm{m}}{ }^{-1}\right)$ obtained for both of these substrates were somewhat lower than those reported for longer non-fluorophorecontaining peptide sequences (about 5- to 50-fold). ${ }^{21}$ The detection of a released fluorophore, however, enables significantly higher signal sensitivity compared to HPLCbased screening methods, thus enabling the low enzyme loading of $30 \mathrm{nM}$, as compared to the $1 \mu \mathrm{M}$ recently reported for an HPLC-based assay. ${ }^{27}$ The fluorometric method furthermore allows for easy performance of continuous rate experiments as long as an appropriate secondary enzyme is chosen. The secondary enzyme in the assay, which serves to 
Scheme 1. (a) Structures of the Analyzed Substrates and (b) Synthesis of Substrates 5a-e

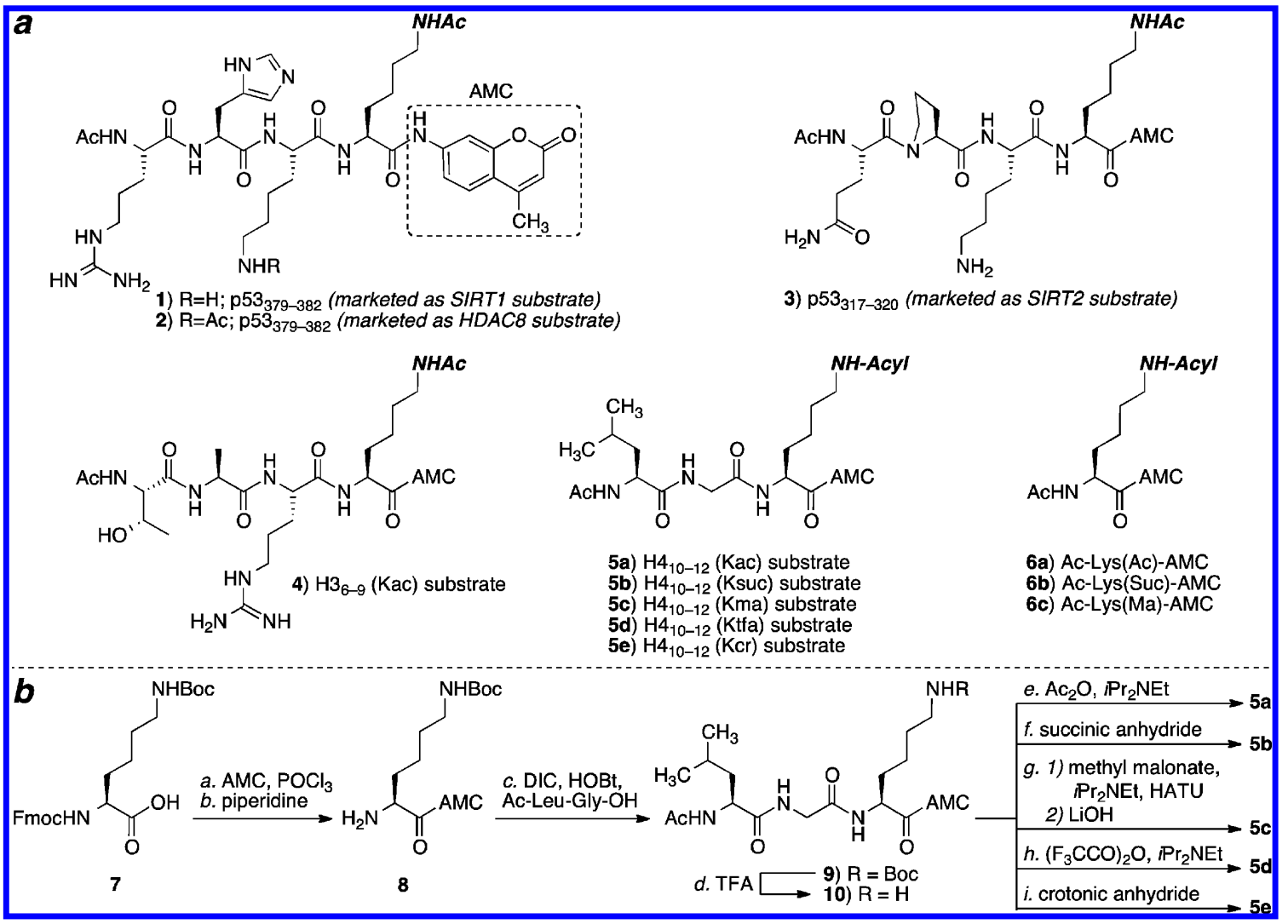

${ }^{a}$ Reagents and conditions: (a) $\mathrm{POCl}_{3}$ (3 equiv), pyridine (10.6 equiv), 7 -amino-4-methylcoumarin (AMC, 1.15 equiv), THF, $0{ }^{\circ} \mathrm{C} \rightarrow \mathrm{rt}, 2.5 \mathrm{~h}$ (quant). ${ }^{26}$ (b) Piperidine (1.1 equiv), $\mathrm{MeCN} \mathrm{CH}_{2} \mathrm{Cl}_{2}, 0^{\circ} \mathrm{C} \rightarrow \mathrm{rt}, 24 \mathrm{~h}$ (88\%). (c) Ac-Leu-Gly-OH (1.02 equiv), diisopropylcarbodiimide (DIC, 1.1 equiv), hydroxybenzotriazole (1.1 equiv), $\mathrm{CH}_{2} \mathrm{Cl}_{2}, \mathrm{rt}, 50 \mathrm{~min}(80 \%)$. (d) Trifluoroacetic acid $-\mathrm{CH}_{2} \mathrm{Cl}_{2}(1: 9, \mathrm{v} / \mathrm{v}), \mathrm{rt}, 30 \mathrm{~min}$. (e) $\mathrm{Ac} c_{2} \mathrm{O}$ (1.5 equiv), $i$ $\mathrm{Pr}_{2} \mathrm{NEt}$ (6 equiv), $\mathrm{CH}_{2} \mathrm{Cl}_{2}, \mathrm{MeCN}, 0{ }^{\circ} \mathrm{C} \rightarrow \mathrm{rt}, 1 \mathrm{~h}$ (34\%, two steps). (f) Succinic anhydride (1.7 equiv), $i-\operatorname{Pr}_{2} \mathrm{NEt}^{\circ}(6 \mathrm{equiv}), \mathrm{CH}_{2} \mathrm{Cl}_{2}, \mathrm{rt}, 55 \mathrm{~min}$ (70\%, 2 steps). (g) (1) Potassium methyl malonate (2 equiv), $i-\mathrm{Pr}_{2} \mathrm{NEt}$ (2.5 equiv), HATU (2 equiv), MeCN, $0{ }^{\circ} \mathrm{C}, 20 \mathrm{~min} ;(2) \mathrm{LiOH}(7.3 \mathrm{equiv})$, THF- $\mathrm{H}_{2} \mathrm{O}$, rt, $15 \mathrm{~min}$ (49\%, 3 steps from 9). (h) Trifluoroacetic anhydride (9 equiv), $i-\mathrm{Pr}_{2} \mathrm{NEt}$ (14 equiv), $\mathrm{CH}_{2} \mathrm{Cl}_{2}, 0{ }^{\circ} \mathrm{C} \rightarrow \mathrm{rt}, 22 \mathrm{~h}(60 \%$ from 9). (i) trans-Crotonic anhydride (1.8 equiv), $i$ - $\mathrm{Pr}_{2} \mathrm{NEt}$ (6 equiv), $\mathrm{CH}_{2} \mathrm{Cl}_{2}, \mathrm{rt}, 10 \mathrm{~min}$ ( $59 \%$ from 9 ).

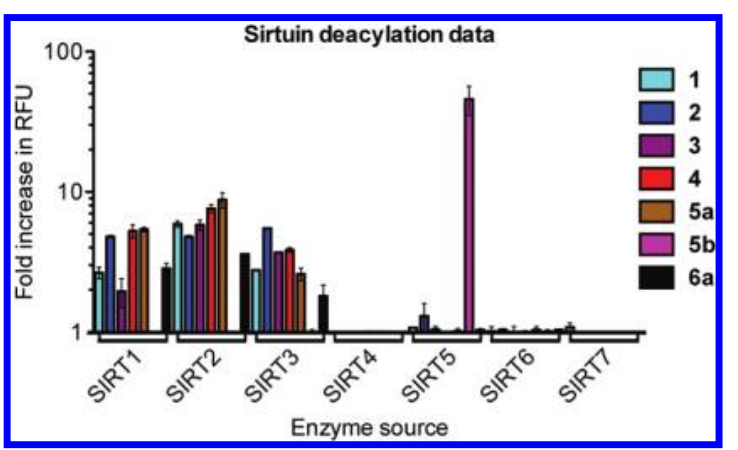

Figure 2. Results of sirtuin deacetylation and desuccinylation of substrate $\mathbf{5 b}$. The data were obtained as end point readings after incubation for $1 \mathrm{~h}$ with each substrate at $37^{\circ} \mathrm{C}$ and represent at least two individual experiments performed in duplicate. The amount of recombinant enzyme added to each reaction was $1 \mu \mathrm{g} / 50 \mu \mathrm{L}$ as determined from stock solution concentrations and purities given by the suppliers (SIRT1-GST fusion protein was used as SIRT1 source). The RFU values are normalized to control wells without sirtuin enzyme present. See Supporting Information Figures S2 and S3 for additional profiling data.

release the fluorophore after the initial deacylation reaction of interest (Supporting Information Figure S1), must meet two important demands to be a successful in situ developer enzyme. First, it must be faster than the initial enzyme in order to

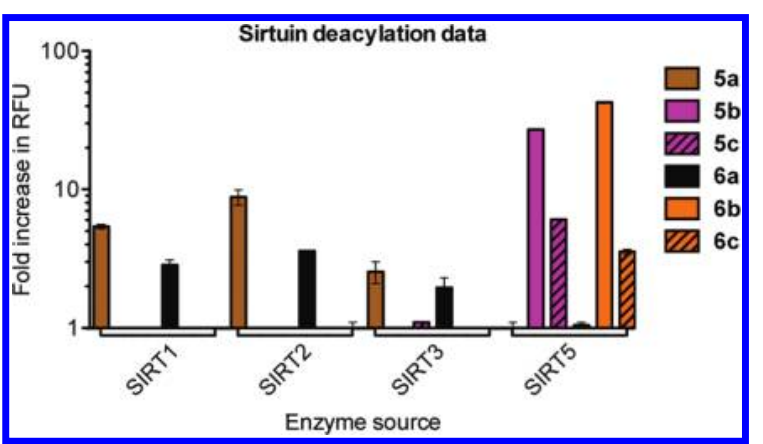

Figure 3. Bar graph for deacylation of substrates $5 a-c$ and $6 a-c$. The data were obtained as end point readings after incubation for $1 \mathrm{~h}$ with each substrate at $37{ }^{\circ} \mathrm{C}$ and represent at least two individual experiments performed in duplicate.

Table 1. Kinetic Parameters for SIRT5 Desuccinylation of Fluorogenic Substrates $5 b$ and $6 b^{a}$

$\begin{array}{ccccc}\text { substrate } & K_{\mathrm{m}}(\mu \mathrm{M}) & V_{\max }\left(\mu \mathrm{M} \mathrm{s}^{-1}\right) & k_{\text {cat }}\left(\mathrm{s}^{-1}\right) & k_{\text {cat }} K_{\mathrm{m}}{ }^{-1}\left(\mathrm{~s}^{-1} \mathrm{M}^{-1}\right) \\ \mathbf{5 b} & 33 \pm 1.8 & 1.9 \times 10^{-3} & 3 \times 10^{-2} & 9.2 \times 10^{2} \\ \mathbf{6 b} & 84 \pm 22 & 5.6 \times 10^{-4} & 9 \times 10^{-3} & 1.1 \times 10^{2}\end{array}$

${ }^{a_{T}}$ The $K_{\mathrm{m}}$ value for NAD measured with substrate $\mathbf{6 b}$ at $200 \mu \mathrm{M}$ was $150 \pm 45 \mu \mathrm{M}$. Michaelis-Menten plot is shown in Figure S5a. 


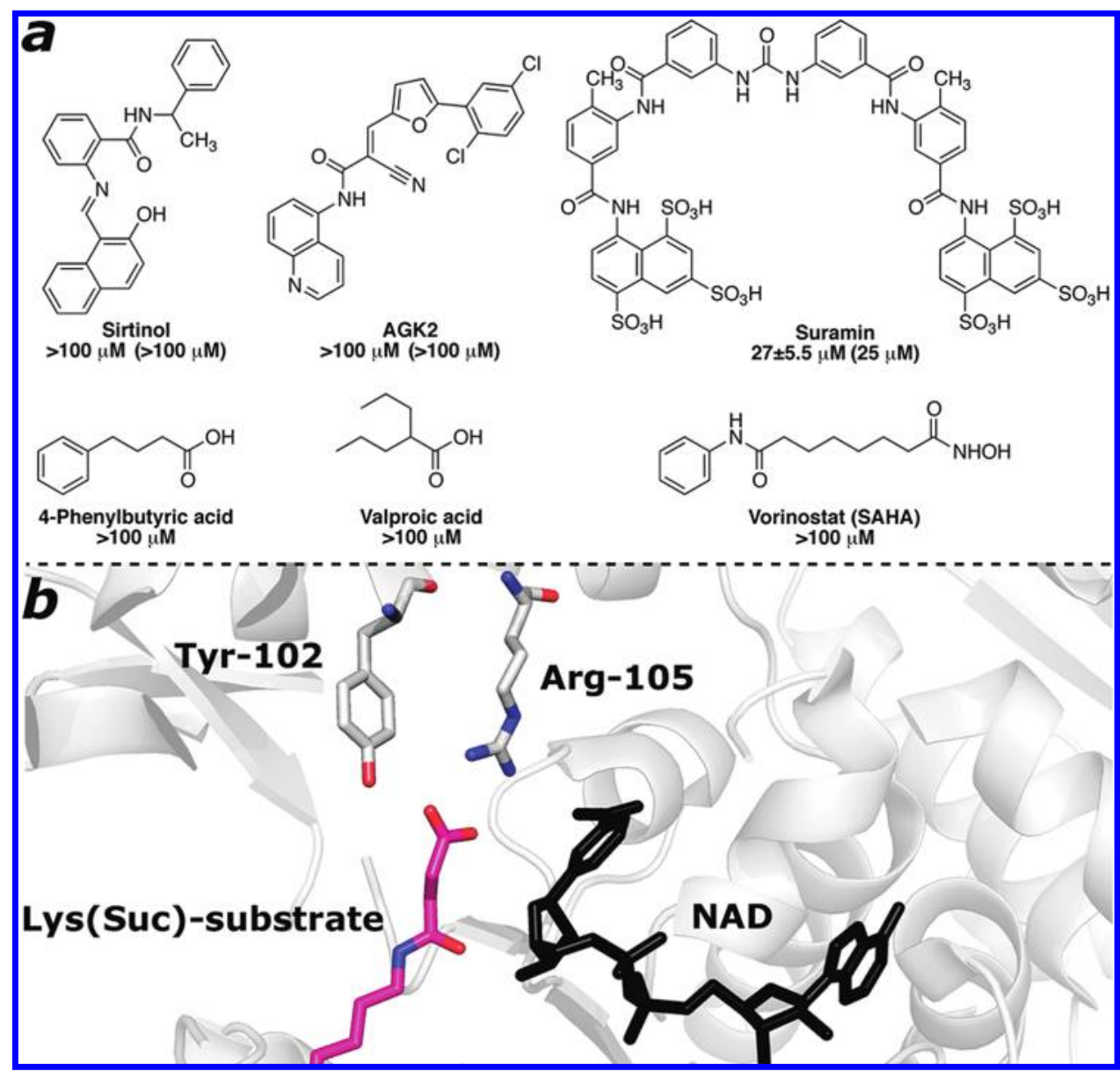

Figure 4. (a) Inhibitor structures and sirtuin 5 inhibition data using substrate $\mathbf{6 b}$. Data are based on two individual assays performed in duplicate. The values in parentheses were previously reported for inhibition of desuccinylation determined in an HPLC-MS based assay with nonfluorogenic peptides. ${ }^{27}$ (b) Geometry of NAD and a succinyllysine-containing peptide cocrystallized with SIRT5 (PDB accession code, 3RIY). ${ }^{21}$

instantaneously process the intermediate product to give a readout, and second, it is essential that the sirtuin enzyme will not be degraded under the assay conditions because of the inherent peptidase activity of the developer.

For the present protocol, we considered the Lys-C protease, which has been used as a mild nondegrading option in HDAC experiments, ${ }^{32,33}$ and trypsin, which is known from end point assays to be very potent. Initial rate experiments for Lys-C at 4 milliunits of enzyme per reaction revealed a $V_{\max }$ that was considerably higher than those of SIRT5 against $\mathbf{5 b}$ and $\mathbf{6 b}$, indicating that Lys-C could be a useful option (Supporting Information Figure S6). With trypsin our concern was the possibility of premature inactivation of SIRT5 due to degradation. At a final concentration of $10 \mu \mathrm{g} / \mathrm{mL}$ of trypsin in the assay, however, the rate increase in fluorescence signal was stable for recordings up to one hour (Supporting Information Figure S7). Protocols were thus established for end point assays, where interference of the developer enzyme is absent, as well as for continuous assays employing two different in situ developer enzymes.

Evaluation of Inhibitors. Though substrate $\mathbf{6 b}$ furnished slightly lower catalytic efficacy than $\mathbf{5 b}$, its simple chemical structure and hence easy accessibility was appealing, and it was therefore decided to perform inhibition experiments using substrate $\mathbf{6 b}$. Initially, $\mathrm{IC}_{50}$ values were determined by nonlinear regression of dose-response data obtained by end point assays. The selected sirtuin inhibitors were the SIRT1 inhibitor sirtinol, $^{34}$ the SIRT2 inhibitor AGK2, ${ }^{35}$ and suramin, ${ }^{36}$ a drug used to treat sleeping sickness. The $\mathrm{IC}_{50}$ values were all in agreement with previously published data obtained using an HPLC-based assay ${ }^{27}$ (Figure 4a, top).

In an attempt to achieve binding affinity by interaction of the active site arginine (Arg-105, Figure 4b) with a carboxylic or hydroxamic acid functionality, three known HDAC inhibitors that are all in clinical use were tested as well (Figure 4a, bottom panel). This proved fruitless with the simple structures tested herein, although evidence that a carboxylic acid moiety may contribute to the binding affinity of SIRT5 inhibitors was recently described for $\varepsilon$ - $N$-thiosuccinyllysine-containing inhibitors, ${ }^{27}$ which were designed by analogy to $\varepsilon$ - $N$-thioacetyllysinecontaining SIRT1 inhibitors. $30,37,38$

Because of previously reported assay artifacts related to fluorophore-containing substrates, which has come under scrutiny with respect to activation of SIRT $1,{ }^{39-42}$ we performed kinetic inhibition experiments using the continuous assay methods discussed vide supra to further validate the developed substrates and protocols. We chose the commercially available inhibitor suramin, which conveniently has been cocrystallized with SIRT5, ${ }^{14}$ for our kinetic studies.

First, we measured steady-state velocities from a titration of substrate $\mathbf{6 b}$ at saturating $\mathrm{NAD}$ concentration and varying concentrations of suramin to give a secondary double reciprocal plot (Lineweaver-Burk plot) ${ }^{43}$ as shown in Supporting Information Figure S8. Intersection of the lines with the $y$ - 

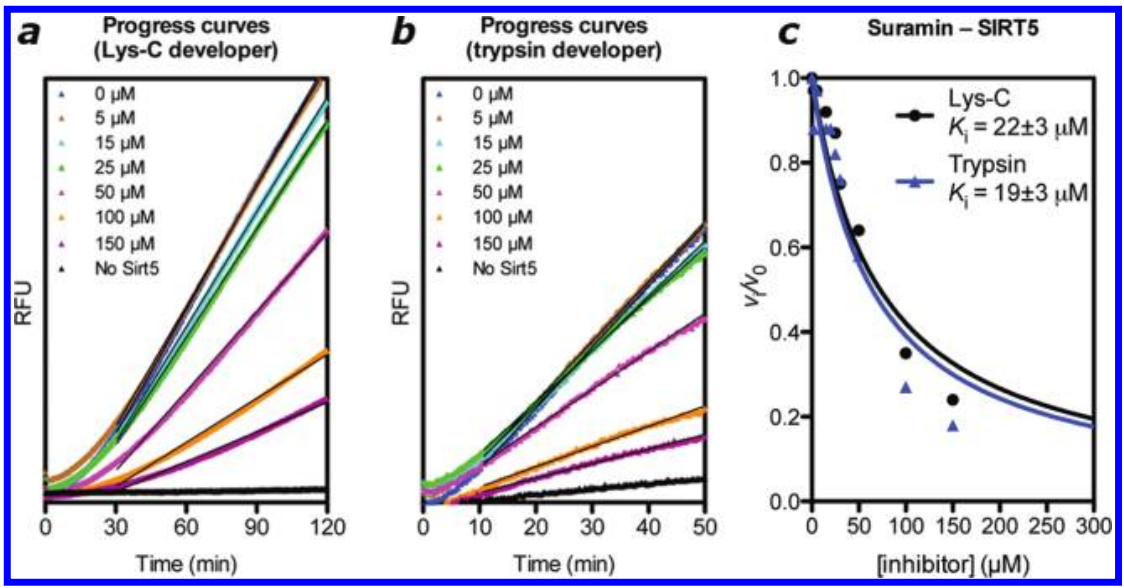

Figure 5. (a) Progress curves for enzyme inhibition of suramin against SIRT5 using substrate $\mathbf{6 b}$ and Lys-C as the secondary enzyme (linear regression lines for the 30-120 min regions are shown in black). (b) Progress curves for suramin inhibition of SIRT5 using substrate $6 \mathbf{b}$ and trypsin as developer (linear regression lines for the $10-50$ min regions are shown in black). (c) Nonlinear fitting of the data to eq $1^{33,44}$ using the GraphPad Prism software.

axis at constant $V_{\max }{ }^{-1}$ shows that the inhibitor is competitive with respect to the fluorogenic substrate (6b), which gratifyingly agrees with the X-ray structure showing that suramin binds to the acyllysine substrate pocket of the enzyme. ${ }^{14}$ Next, we measured progression curves for SIRT5 desuccinylase activity in the presence of varying concentrations of suramin using the two different developer enzymes discussed. When using Lys-C as the coupled secondary enzyme, we observed a lag time of almost 30 min before the system reached a steady state. On the other hand, the resulting progress curves remained linear up to $2 \mathrm{~h}$ (Figure 5a). Trypsin development allowed for the system to reach steady state after just 5-10 min, giving rise to linear curves up to at least $50 \mathrm{~min}$ (Figure 5b). Linear graphs in these plots represent a constant increase in the fluorescence signal, which in turn reflects a constant turnover rate of the SIRT5 enzyme in agreement with a fast-on-fast-off mode of inhibition. Finally, fitting the data to eq 1 , which is in accord with the fast-on-fast-off mechanism, furnished similar $K_{\mathrm{i}}$ values regardless of the developer enzyme used (Figure 5c). To our knowledge, these findings conclude the first disclosure of a kinetic investigation of SIRT5 inhibition using the progression curve method.

$$
\frac{v_{\mathrm{i}}}{v_{0}}=\left(\frac{[\mathrm{I}]}{K_{\mathrm{i}}\left(1+\frac{[\mathrm{S}]}{K_{\mathrm{m}}}\right)}+1\right)^{-1}
$$

\section{CONCLUSIONS}

In summary, we have evaluated the activities of the seven human sirtuin hydrolases against a series of fluorogenic substrates in vitro. The tested substrate collection was designed to address enzyme specificities toward the most commonly used commercial substrates as well as the recently discovered lysine post-translational modifications (i.e., Kma, Ksuc, and $\mathrm{Kcr}) .{ }^{22}$ Convergent synthetic routes for preparation of these new chemotypes were devised to gain easy access to the substrate collection.

Our screening confirmed that SIRT1-3 all exhibit relatively broad-spectrum deacetylase activities. Sirtuins 4,6 , and 7 were practically inactive under our conditions, which is in agreement with previous literature reporting lack of SIRT4 activity and significantly lower deacetylase activities of SIRT6 and SIRT7 compared to SIRT $1-3 .{ }^{18}$ These findings, however, do not rule out that these enzymes may deacylate substrates not yet discovered. Sirtuin 5, on the other hand, exhibited somewhat surprisingly low deacetylase activities but very potent demalonylase and desuccinylase activities as recently described for nonfluorogenic peptide substrates.

Thus, two new substrates were discovered, which enable highly efficient SIRT5 desuccinylation activity at significantly lower enzyme loading than previously described. As such, these readily prepared substrates should be suitable for screening efforts toward the discovery of novel SIRT5 inhibitor compounds. Furthermore, optimized conditions for facile kinetic investigations of SIRT5 interaction with substrates and/or inhibitors were developed, which will be valuable for mechanistic investigations. The well-known inhibitor suramin, which has been cocrystallized with SIRT5, was used to validate our two different continuous assay protocols by performing progression curve experiments.

Additionally, the results of the first decrotonylation experiments performed with sirtuin enzymes indicated that sirtuins are not likely to be potent decrotonylases.

\section{EXPERIMENTAL METHODS}

Materials. Recombinant SIRT1-GST fusion protein, SIRT2, and Lys-C (Lysobacter enzymogenes) were purchased from Merck-Millipore (Darmstadt, Germany), and SIRT1 (full length His-tagged), SIRT3, SIRT5, and SIRT6 were from Enzo Life Sciences (Postfach, Switzerland). Recombinant SIRT4 and SIRT7 were from Abnova (Taipei, Taiwan). Sirtuin assay buffer was prepared as described in the Biomol International product sheets BML-AK-555 [Tris-Cl (50 mM), $\mathrm{NaCl}(137 \mu \mathrm{M}), \mathrm{KCl}(2.7 \mu \mathrm{M}), \mathrm{MgCl}_{2}(1 \mu \mathrm{M}), \mathrm{pH} 8.0$, and bovine serum albumin $(1 \mathrm{mg} / \mathrm{mL})]$. The SIRT2 substrate (3), suramin, sirtinol, and AGK2 inhibitors were from Enzo Life Sciences (Postfach, Switzerland). 4-Phenylbutyric acid, valproic acid, NAD, and trypsin (10 000 units/mg, TPCK treated from bovine pancreas) were from Sigma-Aldrich (Steinheim, Germany).

Sirtuin Deacylation Assays. In brief, all reactions were performed in black low binding NUNC 96-well microtiter plates. End point assays were performed by incubation of the appropriate substrate, $\mathrm{NAD}$, sirtuin, and inhibitor (if applicable) in assay buffer ( $50 \mu \mathrm{L}$ final volume). Control wells without enzyme were included in each plate. After $1 \mathrm{~h}$ at $37{ }^{\circ} \mathrm{C}$, a developer mixture $(50 \mu \mathrm{L})$ containing nicotinamide $(2 \mathrm{mM})$ and trypsin $\left(0.4 \mathrm{mg} \mathrm{mL}^{-1}\right)$ was added, and the assay was incubated for $15-30 \mathrm{~min}$ at room temperature before the 
plates were analyzed using a Perkin-Elmer Enspire plate reader with excitation at $360 \mathrm{~nm}$ and emission at $460 \mathrm{~nm}$. Rate experiments for determination of kinetic parameters were performed by incubation of substrate, $\mathrm{NAD}$, and sirtuin in assay buffer ( $100 \mu \mathrm{L}$ final volume) with in situ fluorophore cleavage by Lys-C or trypsin. Fluorescence readings were recorded every $30 \mathrm{~s}$ for at least $30 \mathrm{~min}$ at $25^{\circ} \mathrm{C}$ to obtain initial linear rates $\nu_{0}\left(\mathrm{RFU} \mathrm{min}^{-1}\right)$ for each concentration. The data were analyzed using GraphPad Prism to afford $K_{\mathrm{m}}(\mu \mathrm{M})$ and $V_{\max }$ (RFU $\left.\min ^{-1}\right)$ values. The $k_{\text {cat }}$ values were calculated based on the [7-amino4-methylcoumarin]-RFU standard curve (Supporting Information Figure S5) and the enzyme purities and concentrations given by the suppliers. The dilution series for dose-response inhibitor experiments were prepared in SIRT assay buffer from DMSO stock solutions. Substrate $\mathbf{6 b}$ was used for inhibition experiments, and the SIRT5 enzyme concentration was $50 \mathrm{ng} /$ well $(\sim 30 \mathrm{nM}$ in $50 \mu \mathrm{L}$ final volume $)$ for end point assays or $200 \mathrm{ng} /$ well $(\sim 60 \mathrm{nM}$ in $100 \mu \mathrm{L}$ final volume) for continuous assays.

Chemistry. General Methods and Materials. 2-Chlorotrityl chloride resin was from Sigma-Aldrich (Milwaukee, WI). All $\alpha$-amino acids, chemicals, and solvents were analytical grade and used without further purification as obtained from commercial suppliers. Anhydrous THF was stored over sodium and freshly distilled prior to use. Anhydrous $\mathrm{MeCN}$ was dried by storage over $3 \AA$ molecular sieves. Anhydrous $\mathrm{CH}_{2} \mathrm{Cl}_{2}, i-\mathrm{Pr}_{2} \mathrm{NEt}$, and pyridine were dried by storage over activated $4 \AA$ molecular sieves. Dry column vacuum chromatography was performed on silica gel 60 (particle size $0.015-0.040 \mathrm{~mm}$ ). Preparative reversed-phase HPLC was performed on a $[250 \mathrm{~mm} \times 20$ $\mathrm{mm}, \mathrm{C} 18(2)$ Phenomenex Luna column $(5 \mu \mathrm{m}, 100 \AA)]$ using an Agilent 1260 LC system equipped with a diode array UV detector and an evaporative light scattering (ELS) detector. A gradient with eluent A (95:5:0.1, water-MeCN-TFA) and eluent B (0.1\% TFA in acetonitrile) rising linearly from $0 \%$ to $95 \%$ of B during $t=5-45 \mathrm{~min}$ was applied at a flow rate of $20 \mathrm{~mL} / \mathrm{min}$. The isolated substrates were lyophilized from the HPLC solvents and stored at $-20{ }^{\circ} \mathrm{C}$. UPLCMS analyses were performed on a Waters Acquity ultrahigh performance liquid chromatography system to confirm purities of $>95 \%$ of all compounds, and high resolution mass spectroscopic measurements were performed using ultrahigh performance liquid chromatography-high resolution mass spectrometry (UHPLCHRMS) on a maXis G3 quadrupole time-of-flight (TOF) mass spectrometer (Bruker Daltonics, Bremen, Germany) equipped with an electrospray (ESI) source. NMR spectra were recorded on a Varian Mercury 300 instrument. ${ }^{1} \mathrm{H}$ NMR, ${ }^{13} \mathrm{C}$ NMR, and ${ }^{19} \mathrm{~F}$ NMR were recorded at 300, 75, and $282 \mathrm{MHz}$, respectively. Chemical shifts are reported in $\mathrm{ppm}$ relative to deuterated solvent peaks as internal standards $\left(\delta_{\mathrm{H}}, \mathrm{DMSO}-d_{6} 2.50 \mathrm{ppm} ; \delta_{\mathrm{C}}, \mathrm{DMSO}-d_{6} 39.52 \mathrm{ppm}\right)$ or external calibration $\left(\delta_{\mathrm{F}}\right)$. Coupling constants $(J)$ are given in hertz $(\mathrm{Hz})$. Multiplicities of ${ }^{1} \mathrm{H}$ NMR signals are reported as follows: $\mathrm{s}$, singlet; d, doublet; dd, doublet of doublets; t, triplet; q, quartet; $\mathrm{p}$, pentet; m, multiplet; br, broad signal. Protons that were exchangeable upon addition of $\mathrm{D}_{2} \mathrm{O}$ are denoted "ex". Assignments of NMR spectra are based on correlation spectroscopy (COSY, HSQC, HMQC, and/ or HMBC spectra).

Ac-Leu-Gly-Lys(Ac)-(7-amino-4-methylcoumarin) (5a). ${ }^{45}$ Crude Ac-Leu-Gly-Lys-(7-amino-4-methylcoumarin) trifluoroacetate salt $(10,49 \mathrm{mg})$ was suspended in anhydrous $\mathrm{CH}_{2} \mathrm{Cl}_{2}(4 \mathrm{~mL})$ and anhydrous $\mathrm{MeCN}(3 \mathrm{~mL})$ at $0{ }^{\circ} \mathrm{C}$ under $\mathrm{N}_{2}$. Hünig's base $(63 \mathrm{mg}, 488$ $\mu \mathrm{mol})$ and $\mathrm{Ac}_{2} \mathrm{O}(12 \mathrm{mg}, 115 \mu \mathrm{mol})$ were added. After being stirred for $1 \mathrm{~h}$ at room temperature, the reaction mixture was taken up in brine. The aqueous phase was extracted with $\mathrm{CH}_{2} \mathrm{Cl}_{2}(3 \times 20 \mathrm{~mL})$, and the combined organic phase was washed with aqueous $\mathrm{HCl}(1 \mathrm{M}$, $2 \times 10 \mathrm{~mL})$. The acidic aqueous phase was back-extracted with $\mathrm{CH}_{2} \mathrm{Cl}_{2}(3 \times 20 \mathrm{~mL})$, then $10 \% \mathrm{MeOH}$ in $\mathrm{CH}_{2} \mathrm{Cl}_{2}(5 \times 20 \mathrm{~mL})$. The combined organic phase was then washed with saturated aqueous $\mathrm{NaHCO}_{3}(10 \mathrm{~mL})$ and the aqueous phase back-extracted with $\mathrm{CH}_{2} \mathrm{Cl}_{2}$ $(3 \times 20 \mathrm{~mL})$. The combined organic phase was dried over $\mathrm{MgSO}_{4}$, filtered, and evaporated to dryness. Preparative reversed-phase HPLC purification of the crude residue afforded $\mathbf{5} \mathbf{a}$ as a white fluffy material after lyophilization (13 mg, 34\% from 9). Full characterization details were not given in the original report and are therefore included here. ${ }^{45}$
${ }^{1} \mathrm{H}$ NMR (DMSO- $\left.d_{6}\right) \delta=10.39\left(\mathrm{~s}, 1 \mathrm{H}, \mathrm{NH}_{\mathrm{AMC}}\right), 8.34(\mathrm{t}, J=5.8,1 \mathrm{H}$, $\left.\mathrm{NH}_{\mathrm{Gly}}\right), 8.11\left(\mathrm{~d}, J=7.2,1 \mathrm{H}, \mathrm{NH}_{\mathrm{Leu}}\right), 8.02\left(\mathrm{~d}, J=7.5,1 \mathrm{H}, \mathrm{NH}_{\alpha, \mathrm{Lys}}\right)$, $7.81\left(\mathrm{t}, J=5.5, \mathrm{NH}_{\varepsilon, \mathrm{Lys}}\right), 7.80\left(\mathrm{~d}, J=2.0,1 \mathrm{H}, \mathrm{H} 8_{\mathrm{AMC}}\right), 7.73(\mathrm{~d}, J=8.7$, $\left.1 \mathrm{H}, \mathrm{HS}_{\mathrm{AMC}}\right), 7.52\left(\mathrm{dd}, J=8.7\right.$ and $\left.2.0,1 \mathrm{H}, \mathrm{H6}_{\mathrm{AMC}}\right), 6.27(\mathrm{~d}, J=1.4$, $\left.1 \mathrm{H}, \mathrm{H}_{\mathrm{AMC}_{\mathrm{MC}}}\right), 4.32-4.41\left(\mathrm{~m}, 1 \mathrm{H}, \mathrm{H}_{\alpha, \mathrm{Lys}}\right), 4.21\left(\mathrm{q}, J=7.4,1 \mathrm{H}, \mathrm{H}_{\alpha, \mathrm{Leu}}\right)$, $3.74\left(\mathrm{~m}_{\mathrm{ABX}, \mathrm{A}} J=16.8\right.$ and $\left.5.7,1 \mathrm{H}, \mathrm{H}_{\alpha, \mathrm{Gly}, \mathrm{A}}\right), 3.71\left(\mathrm{~m}_{\mathrm{ABX}, \mathrm{B}}, J=16.8\right.$ and $\left.5.9,1 \mathrm{H}, \mathrm{H}_{\alpha, \mathrm{Gly}, \mathrm{B}}\right), 3.00\left(\mathrm{q}, J=6.1,2 \mathrm{H}, \mathrm{CH}_{2, \varepsilon, \mathrm{Lys}}\right), 2.40(\mathrm{~d}, J=1.3,3 \mathrm{H}$, $\left.\mathrm{CH}_{3, \mathrm{AMC}}\right), 1.84\left(\mathrm{~s}, 3 \mathrm{H}, \mathrm{CH}_{3} \mathrm{CONH}_{\mathrm{Leu}}\right), 1.77$ (s, $3 \mathrm{H}, \mathrm{CH}_{3} \mathrm{CONH}_{\varepsilon, \mathrm{Lys}}$ ), 1.51-1.74 (m, $3 \mathrm{H}, \mathrm{CH}_{\gamma, \text { Leu }}$ and $\left.\mathrm{CH}_{2, \beta, \text { Lys }}\right), 1.16-1.50(\mathrm{~m}, 6 \mathrm{H}$, $\mathrm{CH}_{2, \beta, \text { Lew }}, \mathrm{CH}_{2, \gamma, \mathrm{Lyy}} \mathrm{CH}_{2, \delta, \mathrm{Lys}}$ ), 0.88 (d, $\left.J=6.5,3 \mathrm{H}, \mathrm{CH}_{3, \text { Leu } \mathrm{A}}\right), 0.83$ $\left(\mathrm{d}, J=6.5,3 \mathrm{H}, \mathrm{CH}_{3, \text { Leu }, \mathrm{B}}\right) \cdot{ }^{13} \mathrm{C}$ NMR (DMSO- $\left.d_{6}\right) \delta=172.9\left(\mathrm{CO}_{\text {Leu }}\right)$, $171.4\left(\mathrm{CO}_{\mathrm{Lys}}\right), 169.7\left(\mathrm{CONH}_{\mathrm{Leu}}\right), 169.02\left(\mathrm{CO}_{\mathrm{Gly}} / \mathrm{CONH}_{\varepsilon, \mathrm{Lys}}\right), 168.96$ $\left(\mathrm{CO}_{\mathrm{Gly}} / \mathrm{CONH}_{\varepsilon, \mathrm{Lys}}\right), 160.0\left(\mathrm{C}_{\mathrm{AMC}}\right), 153.6\left(\mathrm{C} 8 \mathrm{a}_{\mathrm{AMC}}\right), 153.1\left(\mathrm{C}_{\mathrm{AMC}}\right)$,

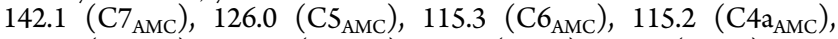
112.4 ( $\left.\mathrm{C}_{\text {AMC }}\right), 105.8$ (C8 $\left.8_{\text {AMC }}\right), 53.6\left(\mathrm{C}_{\alpha, \mathrm{Lys}}\right), 51.5\left(\mathrm{C}_{\alpha, \mathrm{Leu}}\right), 42.0$ $\left(\mathrm{C}_{\alpha, \text { Gly }}\right), 40.5\left(\mathrm{C}_{\beta, \text { Leu }}\right), 38.3\left(\mathrm{C}_{\varepsilon, \text { Lys }}\right), 31.4\left(\mathrm{C}_{\beta, \text { Lys }}\right), 28.9\left(\mathrm{C}_{\delta, \text { Lys }}\right), 24.2$ $\left(\mathrm{C}_{\gamma, \text { Leu }}\right), 22.9\left(\mathrm{CH}_{3, \text { Leu } \mathrm{A}}\right), 22.6\left(\mathrm{C}_{\gamma, \text { Lys }}\right), 22.5\left(\mathrm{CH}_{3} \mathrm{CO}\right), 21.7$ $\left(\mathrm{CH}_{3, \text { Leu }, \mathrm{B}}\right), 18.0\left(\mathrm{CH}_{3, \mathrm{AMC}}\right)$. UPLC-MS $t_{\mathrm{R}}=1.49 \mathrm{~min}, \mathrm{~m} / \mathrm{z} 558.3$ $\left([\mathrm{M}+\mathrm{H}]^{+}, \mathrm{C}_{28} \mathrm{H}_{40} \mathrm{~N}_{5} \mathrm{O}_{7}^{+}\right.$calcd 558.3). HRMS $m / z 558.2916([\mathrm{M}+$ $\mathrm{H}]^{+}, \mathrm{C}_{28} \mathrm{H}_{40} \mathrm{~N}_{5} \mathrm{O}_{7}^{+}$calcd 558.2922).

Ac-Leu-Gly-Lys(succinyl)-(7-amino-4-methylcoumarin) (5b). Crude Ac-Leu-Gly-Lys-(7-amino-4-methylcoumarin) trifluoroacetate salt $(10,50 \mathrm{mg})$ was suspended in anhydrous $\mathrm{CH}_{2} \mathrm{Cl}_{2}(2 \mathrm{~mL})$ and $i-$ $\mathrm{Pr}_{2} \mathrm{NEt}(0.1 \mathrm{~mL})$ under $\mathrm{N}_{2}$ at room temperature. Succinic anhydride (13 $\mathrm{mg}, 133 \mu \mathrm{mol}$ ) was added, immediately resulting in a clear solution. After being stirred for $55 \mathrm{~min}$, the reaction mixture was evaporated to dryness. Preparative reversed-phase HPLC purification of the crude residue afforded Ac-Leu-Gly-Lys(succinyl)-(7-amino-4methylcoumarin) (5b) as a white fluffy material after lyophilization $\left(29 \mathrm{mg}, 70 \%\right.$ from 9). ${ }^{1} \mathrm{H}$ NMR (DMSO- $\left.d_{6}\right) \delta 10.38\left(\mathrm{~s}, 1 \mathrm{H}, \mathrm{NH}_{\text {AMC }}\right)$, $8.35\left(\mathrm{t}, J=5.8,1 \mathrm{H}, \mathrm{NH}_{\mathrm{Gly}}\right), 8.11\left(\mathrm{~d}, J=7.3,1 \mathrm{H}, \mathrm{NH}_{\mathrm{Leu}}\right), 8.02(\mathrm{~d}, J=$ $\left.7.5,1 \mathrm{H}, \mathrm{NH}_{\alpha, \mathrm{Lys}}\right), 7.83\left(\mathrm{t}, J=5.5,1 \mathrm{H}, \mathrm{NH}_{\varepsilon, \mathrm{Lys}}\right), 7.80(\mathrm{~d}, J=2.0,1 \mathrm{H}$, $\left.\mathrm{H} 8_{\text {AMC }}\right), 7.72\left(\mathrm{~d}, J=8.7,1 \mathrm{H}, \mathrm{H}_{\text {AMC }}\right), 7.52(\mathrm{dd}, J=8.7,2.0,1 \mathrm{H}$ $\mathrm{H}_{\mathrm{AMC}}$ ), 6.27 (d, $\left.J=1.2,1 \mathrm{H}, \mathrm{H} 3_{\mathrm{AMC}}\right), 4.32-4.42\left(\mathrm{~m}, 1 \mathrm{H}, \mathrm{H}_{\alpha, \mathrm{Lys}}\right), 4.22$ $\left(\mathrm{q}, J=7.4,1 \mathrm{H}, \mathrm{H}_{\alpha, \mathrm{Leu}}\right), 3.74\left(\mathrm{~m}_{\mathrm{ABX}, \mathrm{A}} J=16.7\right.$ and $\left.5.5,1 \mathrm{H}, \mathrm{H}_{\alpha, \mathrm{Gly}, \mathrm{A}}\right)$, $3.71\left(\mathrm{~m}_{\mathrm{ABX}, \mathrm{B}}, J=16.7,5.8,1 \mathrm{H}, \mathrm{H}_{\alpha, \mathrm{Gly}, \mathrm{B}}\right), 3.01\left(\mathrm{q}, J=6.3,2 \mathrm{H}, \mathrm{CH}_{2, \varepsilon, \mathrm{Lys}}\right)$, 2.34-2.42 (m, 5H, $\left.\mathrm{CH}_{3, \mathrm{AMC}}, \mathrm{HO}_{2} \mathrm{CCH}_{2}\right), 2.23-2.32(\mathrm{~m}, 2 \mathrm{H}$, $\left.\mathrm{CH}_{2} \mathrm{CONH}_{\varepsilon, \mathrm{Lys}}\right), 1.84\left(\mathrm{~s}, 3 \mathrm{H}, \mathrm{CH}_{3} \mathrm{CONH}_{\mathrm{Leu}}\right), 1.51-1.77(\mathrm{~m}, 3 \mathrm{H}$, $\mathrm{CH}_{\gamma, \text { Lew }} \mathrm{CH}_{2, \beta, \text { Lys }}$ ), $1.18-1.51$ (m, 6H, $\mathrm{CH}_{2, \beta, \text { Lew }} \mathrm{CH}_{2, \gamma, \text { Lys }} \mathrm{CH}_{2, \delta, \text { Lys }}$ ), $0.88\left(\mathrm{~d}, J=6.5,3 \mathrm{H}, \mathrm{CH}_{3, \text { Leu, } \mathrm{A}}\right), 0.83\left(\mathrm{~d}, J=6.4,3 \mathrm{H}, \mathrm{CH}_{3, \text { Leu }, \mathrm{B}}\right) .{ }^{3} \mathrm{C}$ NMR (DMSO-d $\left.d_{6}\right) \delta 173.9\left(\mathrm{CO}_{2} \mathrm{H}\right), 173.0\left(\mathrm{CO}_{\text {Leu }}\right), 171.5\left(\mathrm{CO}_{\mathrm{Lys}}\right)$, $170.8\left(\mathrm{NH}_{\varepsilon, \mathrm{Lys}} \mathrm{CO}\right), 169.8\left(\mathrm{CH}_{3} \mathrm{CO}\right), 169.0\left(\mathrm{CO}_{\mathrm{Gly}}\right), 160.1\left(\mathrm{C}_{\mathrm{AMC}}\right)$,

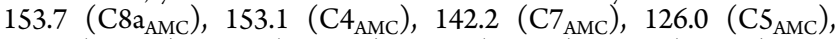

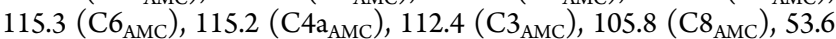
$\left(\mathrm{C}_{\alpha, \text { Lys }}\right), 51.5\left(\mathrm{C}_{\alpha, \text { Leu }}\right), 42.1\left(\mathrm{C}_{\alpha, \text { Gly }}\right), 40.5\left(\mathrm{C}_{\beta, \text { Leu }}\right), 38.4\left(\mathrm{C}_{\varepsilon, \text { Lys }}\right), 31.4$ $\left(\mathrm{C}_{\beta, \mathrm{Lys}}\right), 30.0\left(\mathrm{CH}_{2} \mathrm{CONH}_{\varepsilon, \mathrm{Lys}}\right), 29.2\left(\mathrm{HO}_{2} \mathrm{CCH}_{2}\right), 28.8\left(\mathrm{C}_{\delta, \mathrm{Lys}}\right), 24.2$ $\left(\mathrm{C}_{\gamma, \text { Leu }}\right), 23.0\left(\mathrm{CH}_{3, \text { Leu }, \mathrm{A}}\right), 22.9\left(\mathrm{C}_{\gamma, \mathrm{Lys}}\right), 22.5\left(\mathrm{CH}_{3} \mathrm{CO}\right), 21.7$ $\left(\mathrm{CH}_{3, \mathrm{Leu}, \mathrm{B}}\right), 18.0\left(\mathrm{CH}_{3, \mathrm{AMC}}\right)$. UPLC-MS $t_{\mathrm{R}}=1.47 \mathrm{~min}, \mathrm{~m} / z 616.5$ $\left([\mathrm{M}+\mathrm{H}]^{+}, \mathrm{C}_{30} \mathrm{H}_{42} \mathrm{~N}_{5} \mathrm{O}_{9}{ }^{+}\right.$calcd 616.3). HRMS $m / z 616.2976([\mathrm{M}+$ $\mathrm{H}]^{+}, \mathrm{C}_{30} \mathrm{H}_{42} \mathrm{~N}_{5} \mathrm{O}_{9}^{+}$calcd 616.2977).

Ac-Leu-Gly-Lys(malonyl)-(7-amino-4-methylcoumarin) (5c). Potassium monomethyl malonate $(50 \mathrm{mg}, 0.319 \mathrm{mmol})$ was suspended in $\mathrm{MeCN}(2 \mathrm{~mL})$ and $i-\mathrm{Pr}_{2} \mathrm{NEt}(0.07 \mathrm{~mL})$ under Ar at 0 ${ }^{\circ} \mathrm{C}$. HATU $(122 \mathrm{mg}, 0.321 \mathrm{mmol})$ was added affording a yellow solution. After preincubation for $5 \mathrm{~min}$, the crude Ac-Leu-Gly-Lys-(7amino-4-methylcoumarin) trifluoroacetate salt $(10,99 \mathrm{mg})$ was added, and the resulting suspension was stirred at $0{ }^{\circ} \mathrm{C}$. After the mixture was stirred for $20 \mathrm{~min}, \mathrm{MeOH}(1 \mathrm{~mL})$ was added, and the reaction mixture was evaporated to dryness. The resulting residue was purified by column chromatography $\left(0-8 \% \mathrm{MeOH}\right.$ in $\left.\mathrm{CH}_{2} \mathrm{Cl}_{2}\right)$, to afford a white foam [Ac-Leu-Gly-Lys((methyl)malonyl)-(7-amino-4-methylcoumarin) $(84 \mathrm{mg})$. UPLC-MS $t_{\mathrm{R}}=1.56 \mathrm{~min}, \mathrm{~m} / z 616.3\left([\mathrm{M}+\mathrm{H}]^{+}\right.$, $\mathrm{C}_{30} \mathrm{H}_{42} \mathrm{~N}_{5} \mathrm{O}_{9}{ }^{+}$calcd 616.3)]. This crude material was dissolved in THF $(1.0 \mathrm{~mL})$ and aqueous $\mathrm{LiOH}(1.0 \mathrm{M}, 1.0 \mathrm{~mL})$. After being stirred for $15 \mathrm{~min}$, the reaction mixture was concentrated to approximately $1 \mathrm{~mL}$, then neutralized by addition of aqueous $\mathrm{HCl}(2 \mathrm{M}, 0.3 \mathrm{~mL})$. The resulting solution was purified by preparative reversed-phase HPLC to afford Ac-Leu-Gly-Lys(malonyl)-(7-amino-4-methylcoumarin) (5c) as a white fluffy material after lyophilization (40 mg, 49\% from 9). ${ }^{1} \mathrm{H}$ $\operatorname{NMR}\left(\mathrm{DMSO}-d_{6}\right) \delta=10.39\left(\mathrm{~s}, 1 \mathrm{H}, \mathrm{NH}_{\mathrm{AMC}}\right), 8.35(\mathrm{t}, J=5.8,1 \mathrm{H}$, 
$\left.\mathrm{NH}_{\text {Gly }}\right), 8.11\left(\mathrm{~d}, J=7.2,1 \mathrm{H}, \mathrm{NH}_{\mathrm{Leu}}\right), 7.99-8.08\left(\mathrm{~m}, 2 \mathrm{H}, \mathrm{NH}_{\alpha, \mathrm{Lys}}\right.$ and $\left.\mathrm{NH}_{\varepsilon, \mathrm{Lys}}\right), 7.80\left(\mathrm{~d}, J=1.9,1 \mathrm{H}, \mathrm{H} 8_{\text {AMC }}\right), 7.72\left(\mathrm{~d}, J=8.7,1 \mathrm{H}, \mathrm{HS}_{\text {AMC }}\right)$, $7.52\left(\mathrm{dd}, J=8.7\right.$ and $\left.2.0,1 \mathrm{H}, \mathrm{H6}_{\text {AMC }}\right), 6.27\left(\mathrm{~d}, J=1.2,1 \mathrm{H}, \mathrm{H}_{\text {AMC }}\right)$, $4.32-4.43\left(\mathrm{~m}, 1 \mathrm{H}, \mathrm{H}_{\alpha, \mathrm{Lys}}\right), 4.22\left(\mathrm{q}, J=7.4,1 \mathrm{H}, \mathrm{H}_{\alpha, \mathrm{Leu}}\right), 3.74\left(\mathrm{~m}_{\mathrm{ABX}, \mathrm{A}} J\right.$ $=16.6$ and 5.7, $\left.1 \mathrm{H}, \mathrm{H}_{\alpha, \mathrm{Gly}, \mathrm{A}}\right), 3.71\left(\mathrm{~m}_{\mathrm{ABX}, \mathrm{B}}, J=16.6\right.$ and $5.6,1 \mathrm{H}$, $\left.\mathrm{H}_{\alpha, \mathrm{Gly}, \mathrm{B}}\right), 3.10\left(\mathrm{~s}, 2 \mathrm{H}, \mathrm{CH}_{2}(\mathrm{CO})_{2}\right), 3.04\left(\mathrm{q}, J=6.5,2 \mathrm{H}, \mathrm{CH}_{2, \varepsilon, \mathrm{Lys}}\right), 2.39$ $\left(\mathrm{d}, J=1.2,3 \mathrm{H}, \mathrm{CH}_{3, \mathrm{AMC}}\right), 1.84\left(\mathrm{~s}, 3 \mathrm{H}, \mathrm{CH}_{3} \mathrm{CO}\right), 1.51-1.79(\mathrm{~m}, 3 \mathrm{H}$, $\mathrm{CH}_{\gamma, \text { Leu }}$ and $\left.\mathrm{CH}_{2, \beta, \text { Lys }}\right), 1.19-1.51\left(\mathrm{~m}, 6 \mathrm{H}, \mathrm{CH}_{2, \beta, \text { Leu }} \mathrm{CH}_{2, \gamma, \mathrm{Lys}}\right.$, and $\left.\mathrm{CH}_{2, \delta, \text { Lys }}\right), 0.88\left(\mathrm{~d}, J=6.5,3 \mathrm{H}, \mathrm{CH}_{3, \text { Leu, }}\right), 0.83(\mathrm{~d}, J=6.4,3 \mathrm{H}$, $\left.\mathrm{CH}_{3, \mathrm{Leu}, \mathrm{B}}\right) \cdot{ }^{13} \mathrm{C}$ NMR (DMSO- $\left.d_{6}\right) \delta=173.0\left(\mathrm{CO}_{\mathrm{Leu}}\right), 171.5\left(\mathrm{CO}_{\mathrm{Lys}}\right)$, $169.8\left(\mathrm{CH}_{3} \mathrm{CO}\right), 169.6\left(\mathrm{CO}_{2} \mathrm{H}\right), 169.1\left(\mathrm{CO}_{\mathrm{Gly}}\right), 165.6\left(\mathrm{CONH}_{\varepsilon, \mathrm{Lys}}\right)$, 160.1 (C2 $\left.{ }_{\mathrm{AMC}}\right), 153.7$ (C8a $\left.\mathrm{CMC}_{\mathrm{AMC}}\right), 153.1$ (C4 $\left.\mathrm{CMC}_{\mathrm{AMC}}\right), 142.2$ (C7 $\left.7_{\mathrm{AMC}}\right)$,

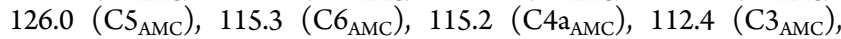
105.8 ( $\left.\mathrm{C}_{\text {AMC }}\right), 53.6\left(\mathrm{C}_{\alpha, \mathrm{Lys}}\right), 51.5\left(\mathrm{C}_{\alpha, \mathrm{Leu}}\right), 42.6\left(\mathrm{CH}_{2}(\mathrm{CO})_{2}\right), 42.1$ $\left(\mathrm{C}_{\alpha, \mathrm{Gly}}\right), 31.4\left(\mathrm{C}_{\beta, \mathrm{Lys}}\right), 28.7\left(\mathrm{C}_{\delta, \mathrm{Lys}}\right), 24.2\left(\mathrm{C}_{\gamma, \mathrm{Leu}}\right), 23.0\left(\mathrm{CH}_{3, \mathrm{Leu}, \mathrm{A}}\right), 22.9$ $\left(\mathrm{C}_{\gamma, \mathrm{Lys}}\right), 22.5\left(\mathrm{CH}_{3} \mathrm{CO}\right), 21.7\left(\mathrm{CH}_{3, \mathrm{Leu}, \mathrm{B}}\right), 18.0\left(\mathrm{CH}_{3, \mathrm{AMC}}\right)$. UPLC-MS $t_{\mathrm{R}}=1.49 \mathrm{~min}, \mathrm{~m} / z 602.3\left([\mathrm{M}+\mathrm{H}]^{+}, \mathrm{C}_{29} \mathrm{H}_{40} \mathrm{~N}_{5} \mathrm{O}_{9}{ }^{+}\right.$calcd 602.3). HRMS $m / z$ 602.2823 $\left([\mathrm{M}+\mathrm{H}]^{+}, \mathrm{C}_{29} \mathrm{H}_{40} \mathrm{~N}_{5} \mathrm{O}_{9}{ }^{+}\right.$calcd 602.2821).

Ac-Leu-Gly-Lys(Tfa)-(7-amino-4-methylcoumarin) $(5 \mathrm{~d}) .^{24}$ Crude Ac-Leu-Gly-Lys-(7-amino-4-methylcoumarin) trifluoroacetate salt $(10,52 \mathrm{mg})$ was suspended in anhydrous $\mathrm{CH}_{2} \mathrm{Cl}_{2}(4 \mathrm{~mL})$ and $\mathrm{MeCN}(3 \mathrm{~mL})$ under $\mathrm{N}_{2}$ at $0{ }^{\circ} \mathrm{C}$. $i-\operatorname{Pr}_{2} \mathrm{NEt}(62 \mathrm{mg}, 477 \mu \mathrm{mol})$ and $\left(\mathrm{CF}_{3} \mathrm{CO}\right)_{2} \mathrm{O}(33 \mathrm{mg}, 159 \mu \mathrm{mol})$ were added, and the mixture was stirred for $100 \mathrm{~min}$. Additional portions of $i-\mathrm{Pr}_{2} \mathrm{NEt}(100 \mu \mathrm{L}, 0.58$ $\mathrm{mmol})$ and $\left(\mathrm{CF}_{3} \mathrm{CO}\right)_{2} \mathrm{O}(127 \mathrm{mg}, 0.61 \mathrm{mmol})$ were added over a time course of $20 \mathrm{~h}$ to drive the reaction to completion. Then the reaction mixture was taken up in aqueous $\mathrm{HCl}(1 \mathrm{M}, 10 \mathrm{~mL})$ and $\mathrm{CH}_{2} \mathrm{Cl}_{2}(20$ $\mathrm{mL})$. The aqueous phase was extracted with $\mathrm{CH}_{2} \mathrm{Cl}_{2}(3 \times 20 \mathrm{~mL})$, and the combined organic phase was washed with aqueous $\mathrm{HCl}(1 \mathrm{M}, 10$ $\mathrm{mL}$ ), after which the aqueous phase was back-extracted with $\mathrm{CH}_{2} \mathrm{Cl}_{2}$ $(3 \times 20 \mathrm{~mL})$. The organic phase was then washed with saturated aqueous $\mathrm{NaHCO}_{3}(10 \mathrm{~mL})$, dried over $\mathrm{MgSO}_{4}$, filtered, and evaporated to dryness. The resulting residue was purified by column chromatography $\left(0-5 \% \mathrm{MeOH}\right.$ in $\left.\mathrm{CH}_{2} \mathrm{Cl}_{2}\right)$, affording the desired AcLeu-Gly-Lys(Tfa)-(7-amino-4-methylcoumarin) (5d) as a white solid (26 mg, 60\% from 9). The ${ }^{13} \mathrm{C}$ NMR data did not correspond fully with previously reported data, since we did not observe additional peaks attributed to a mixture of conformers. ${ }^{24}{ }^{1} \mathrm{H}$ NMR (DMSO- $\left.d_{6}\right) \delta$ $=10.39\left(\mathrm{~s}, 1 \mathrm{H}, \mathrm{NH}_{\mathrm{AMC}}\right), 9.42\left(\mathrm{t}, J=5.7,1 \mathrm{H}, \mathrm{NHCOCF}_{3}\right), 8.34(\mathrm{t}, J=$ $\left.5.8,1 \mathrm{H}, \mathrm{NH}_{\mathrm{Gly}}\right), 8.10\left(\mathrm{~d}, J=7.3,1 \mathrm{H}, \mathrm{NH}_{\mathrm{Leu}}\right), 8.05(\mathrm{~d}, J=7.5,1 \mathrm{H}$, $\left.\mathrm{NH}_{\text {Lys }}\right), 7.79\left(\mathrm{~d}, J=2.0,1 \mathrm{H}, \mathrm{H} 8_{\text {AMC }}\right), 7.72\left(\mathrm{~d}, J=8.7,1 \mathrm{H}, \mathrm{H} 5_{\text {AMC }}\right.$ ), 7.51 (dd, $J=8.7$ and $\left.2.0,1 \mathrm{H}, \mathrm{H}_{\text {AMC }}\right), 6.27$ (d, $J=1.4,1 \mathrm{H}, \mathrm{H}_{\text {AMC }}$ ), $4.32-4.44\left(\mathrm{~m}, 1 \mathrm{H}, \mathrm{H}_{\alpha, \mathrm{Lys}}\right), 4.22\left(\mathrm{q}, J=7.5,1 \mathrm{H}, \mathrm{H}_{\alpha, \text { Leu }}\right), 3.74\left(\mathrm{~m}_{\mathrm{ABX}, \mathrm{A} J} J\right.$ $=16.8$ and 5.4, $\left.1 \mathrm{H}, \mathrm{H}_{\alpha, \mathrm{Gly}, \mathrm{A}}\right), 3.71\left(\mathrm{~m}_{\mathrm{ABX}, \mathrm{B}}, J=16.8\right.$ and $5.7,1 \mathrm{H}$, $\left.\mathrm{H}_{\alpha, \mathrm{Gly}, \mathrm{B}}\right), 3.16\left(\mathrm{q}, J=6.7,2 \mathrm{H}, \mathrm{CH}_{2, \varepsilon, \mathrm{Lys}}\right), 2.40(\mathrm{~d}, J=1.4,3 \mathrm{H}$, $\mathrm{CH}_{3, \mathrm{AMC}}$ ), 1.84 (s, 3H, $\left.\mathrm{CH}_{3} \mathrm{CONH}_{\mathrm{Leu}}\right), 1.19-1.80\left(\mathrm{~m}, 9 \mathrm{H}, \mathrm{CH}_{2, \beta, \mathrm{Leu}}\right.$, $\mathrm{CH}_{\gamma, \mathrm{Lew}} \mathrm{CH}_{2, \beta, \mathrm{Lys}}, \mathrm{CH}_{2, \gamma, \mathrm{Lys}}$, and $\left.\mathrm{CH}_{2, \delta, \mathrm{Lys}}\right), 0.88(\mathrm{~d}, J=6.5,3 \mathrm{H}$, $\left.\mathrm{CH}_{3, \text { Leu }, \mathrm{A}}\right), 0.83\left(\mathrm{~d}, J=6.4,3 \mathrm{H}, \mathrm{CH}_{3, \text { Leu }, \mathrm{B}}\right) .{ }^{13} \mathrm{C}$ NMR (DMSO- $\left.d_{6}\right) \delta=$ $172.9\left(\mathrm{CO}_{\mathrm{Leu}}\right), 171.4\left(\mathrm{CO}_{\mathrm{Lys}}\right), 169.7\left(\mathrm{CH}_{3} \mathrm{CO}\right), 169.0\left(\mathrm{CO}_{\mathrm{Gly}}\right), 160.0$ $\left(\mathrm{C}_{\text {AMC }}\right), 156.1\left(\mathrm{q}, J=35.9, \mathrm{COCF}_{3}\right), 153.6\left(\mathrm{C} 8 \mathrm{a}_{\mathrm{AMC}}\right), 153.1$ $\left(\mathrm{C}_{\mathrm{AMC}}\right), 142.1$ ( $\left.\mathrm{C}_{\mathrm{AMC}}\right), 126.0\left(\mathrm{C5}_{\mathrm{AMC}}\right), 116.0\left(\mathrm{q}, J=288.0, \mathrm{CF}_{3}\right)$,

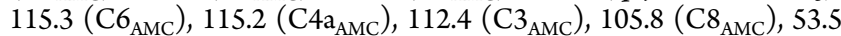
$\left(\mathrm{C}_{\alpha, \text { Lys }}\right), 51.5\left(\mathrm{C}_{\alpha, \text { Leu }}\right), 42.0\left(\mathrm{C}_{\alpha, \text { Gly }}\right), 40.5\left(\mathrm{C}_{\beta, \text { Leu }}\right), 39.0\left(\mathrm{C}_{\varepsilon, \mathrm{Lys}}\right), 31.3$ $\left(\mathrm{C}_{\beta, \text { Lys }}\right), 28.0\left(\mathrm{C}_{\delta, \text { Lys }}\right), 24.2\left(\mathrm{C}_{\gamma, \text { Leu }}\right), 22.9\left(\mathrm{CH}_{3, \text { Leu }, \mathrm{A}}\right), 22.7\left(\mathrm{C}_{\gamma, \mathrm{Lys}}\right), 22.5$ $\left(\mathrm{CH}_{3} \mathrm{CO}\right), 21.6\left(\mathrm{CH}_{3, \mathrm{Leu}, \mathrm{B}}\right), 18.0\left(\mathrm{CH}_{3, \mathrm{AMC}}\right) \cdot{ }^{19} \mathrm{~F}$ NMR $\left(\mathrm{DMSO}-d_{6}\right) \delta$ $=-75.7\left(\mathrm{CF}_{3}\right)$. UPLC-MS $t_{\mathrm{R}}=1.77 \mathrm{~min}, \mathrm{~m} / z 612.4\left([\mathrm{M}+\mathrm{H}]^{+}\right.$, $\mathrm{C}_{28} \mathrm{H}_{37} \mathrm{~F}_{3} \mathrm{~N}_{5} \mathrm{O}_{7}^{+}$calcd 612.3). HRMS $m / z$ 612.2646 ([M $\left.+\mathrm{H}\right]^{+}$, $\mathrm{C}_{28} \mathrm{H}_{37} \mathrm{~F}_{3} \mathrm{~N}_{5} \mathrm{O}_{7}^{+}$calcd 612.2640).

Ac-Leu-Gly-Lys(crotonyl)-(7-amino-4-methylcoumarin) (5e). Crotonoic acid $(5.03 \mathrm{~g}, 58.4 \mathrm{mmol})$ was suspended in $\mathrm{CH}_{2} \mathrm{Cl}_{2}$ (50 $\mathrm{mL}$ ) under $\mathrm{N}_{2}$, and the mixture was stirred at $0{ }^{\circ} \mathrm{C}$. DIC $(6.0 \mathrm{~mL}, 38.7$ $\mathrm{mmol}$ ) was added portionwise. The reaction mixture was stirred for 3 days and then evaporated to dryness. The resulting residue was taken up in heptane $(50 \mathrm{~mL})$, and the white precipitate was filtered off and washed with heptane $(3 \times 10 \mathrm{~mL})$. The combined organic phases were evaporated to dryness to afford crude trans-crotonic anhydride, which was used directly in the acylation step. Crude Ac-Leu-Gly-Lys-(7amino-4-methylcoumarin) trifluoroacetate salt $(\mathbf{1 0}, 50 \mathrm{mg})$ was suspended in anhydrous $\mathrm{CH}_{2} \mathrm{Cl}_{2}(2.5 \mathrm{~mL})$ and $i-\mathrm{Pr}_{2} \mathrm{NEt}(0.1 \mathrm{~mL})$ under $\mathrm{N}_{2}$ at room temperature. Crotonyl anhydride $(22 \mathrm{mg}, 143$ $\mu \mathrm{mol}$ ) was added, resulting in a clear solution after stirring for $30 \mathrm{~s}$. The reaction mixture was stirred for $10 \mathrm{~min}$ and was then evaporated to dryness. The resulting crude was purified by preparative reversedphase HPLC to afford the title compound as a white fluffy material after lyophilization (24 mg, 59\% from 9). ${ }^{1} \mathrm{H}$ NMR (DMSO- $\left.d_{6}\right) \delta=$ $10.38\left(\mathrm{~s}, 1 \mathrm{H}, \mathrm{NH}_{\mathrm{AMC}}\right), 8.34\left(\mathrm{t}, J=5.8,1 \mathrm{H}, \mathrm{NH}_{\mathrm{Gly}}\right), 8.11(\mathrm{~d}, J=7.3$, $\left.1 \mathrm{H}, \mathrm{NH}_{\mathrm{Leu}}\right), 8.03\left(\mathrm{~d}, J=7.5,1 \mathrm{H}, \mathrm{NH}_{\mathrm{Lys}}\right), 7.85\left(\mathrm{t}, J=5.6,1 \mathrm{H}, \mathrm{NH}_{\varepsilon, \mathrm{Lys}}\right)$, $7.79\left(\mathrm{~d}, J=2.0,1 \mathrm{H}, \mathrm{H} 8_{\text {AMC }}\right), 7.72\left(\mathrm{~d}, J=8.7,1 \mathrm{H}, \mathrm{H} 5_{\text {AMC }}\right), 7.52(\mathrm{dd}, J$ $=8.7$ and $\left.2.0,1 \mathrm{H}, \mathrm{H6}_{\mathrm{AMC}}\right), 6.56(\mathrm{dq}, J=15.3$ and $6.9,1 \mathrm{H}, \mathrm{CH}=$ $\left.\mathrm{CHCH}_{3}\right), 6.27\left(\mathrm{~d}, J=1.4,1 \mathrm{H}, \mathrm{H} 3_{\text {AMC }}\right), 5.86(\mathrm{dq}, J=15.3$ and $1.6,1 \mathrm{H}$, $\left.\mathrm{CH}=\mathrm{CHCH}_{3}\right), 4.30-4.42\left(\mathrm{~m}, 1 \mathrm{H}, \mathrm{H}_{\alpha, \mathrm{Lys}}\right), 4.22(\mathrm{q}, J=7.4,1 \mathrm{H}$, $\left.\mathrm{H}_{\alpha, \mathrm{Leu}}\right), 3.74\left(\mathrm{~m}_{\mathrm{ABX}, \mathrm{A}}, J=16.9\right.$ and $\left.5.4,1 \mathrm{H}, \mathrm{H}_{\alpha, \mathrm{Gly}, \mathrm{A}}\right), 3.71\left(\mathrm{~m}_{\mathrm{ABX}, \mathrm{B}}, J=\right.$ 16.9 and 6.1, $\left.1 \mathrm{H}, \mathrm{H}_{\alpha, \mathrm{Gly}, \mathrm{B}}\right), 3.08\left(\mathrm{q}, J=6.4,2 \mathrm{H}, \mathrm{CH}_{2, \varepsilon, \mathrm{Lys}}\right), 2.39(\mathrm{~d}, J=$ $\left.1.3,3 \mathrm{H}, \mathrm{CH}_{3, \mathrm{AMC}}\right), 1.84\left(\mathrm{~s}, 3 \mathrm{H}, \mathrm{CH}_{3} \mathrm{CONH}_{\mathrm{Leu}}\right), 1.75$ (dd, $J=6.9$ and $\left.1.6,3 \mathrm{H}, \mathrm{CH}=\mathrm{CHCH}_{3}\right), 1.51-1.72\left(\mathrm{~m}, 3 \mathrm{H}, \mathrm{CH}_{\gamma, \mathrm{Leu}}\right.$ and $\left.\mathrm{CH}_{2, \beta, \mathrm{Lys}}\right)$, 1.17-1.51 (m, 6H, $\mathrm{CH}_{2, \beta, \text { Lew }} \mathrm{CH}_{2, \gamma, \mathrm{Lys}}$, and $\left.\mathrm{CH}_{2, \delta, \mathrm{Lys}}\right), 0.88(\mathrm{~d}, J=6.5$, $3 \mathrm{H}, \mathrm{CH}_{3, \text { Leu } \mathrm{A}}$ ), $0.83\left(\mathrm{~d}, J=6.4,3 \mathrm{H}, \mathrm{CH}_{3, \text { Leu } \mathrm{B}}\right) .{ }^{13} \mathrm{C}$ NMR (DMSO- $d_{6}$ ) $\delta=172.9\left(\mathrm{CO}_{\mathrm{Leu}}\right), 171.4\left(\mathrm{CO}_{\mathrm{Lys}}\right), 169.7\left(\mathrm{CH}_{3} \mathrm{CO}\right), 169.0\left(\mathrm{CO}_{\mathrm{Gly}}\right)$, $164.8\left(\mathrm{NHCO}_{\varepsilon, \mathrm{Lys}}\right), 160.0\left(\mathrm{C}_{\mathrm{AMC}}\right), 153.6\left(\mathrm{C} 8 \mathrm{a}_{\mathrm{AMC}}\right), 153.1\left(\mathrm{C}_{\mathrm{AMC}}\right)$, $142.1\left(\mathrm{C}_{\mathrm{AMC}}\right), 137.3\left(\mathrm{CH}=\mathrm{CHCH}_{3}\right), 126.0\left(\mathrm{Cs}_{\mathrm{AMC}}, \mathrm{CH}=\mathrm{CHCH}_{3}\right)$,

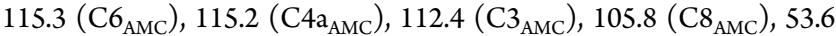
$\left(\mathrm{C}_{\alpha, \mathrm{Lys}}\right), 51.5\left(\mathrm{C}_{\alpha, \mathrm{Leu}}\right), 42.0\left(\mathrm{C}_{\alpha, \mathrm{Gly}}\right), 40.5\left(\mathrm{C}_{\beta, \mathrm{Leu}}\right), 39.0\left(\mathrm{C}_{\varepsilon, \mathrm{Lys}}\right), 31.4$ $\left(\mathrm{C}_{\beta, \mathrm{Lys}}\right), 28.9\left(\mathrm{C}_{\delta, \mathrm{Lys}}\right), 24.2\left(\mathrm{C}_{\gamma, \mathrm{Leu}}\right), 23.0\left(\mathrm{CH}_{3, \mathrm{Leu}, \mathrm{A}}\right), 22.9\left(\mathrm{C}_{\gamma, \mathrm{Lys}}\right), 22.5$ $\left(\mathrm{CH}_{3} \mathrm{CO}\right), 21.7\left(\mathrm{CH}_{3, \mathrm{Leu} B}\right), 18.0\left(\mathrm{CH}_{3, \mathrm{AMC}}\right), 17.3\left(\mathrm{CH}=\mathrm{CHCH}_{3}\right)$. UPLC-MS $t_{\mathrm{R}}=1.62 \mathrm{~min}, m / z 584.4\left([\mathrm{M}+\mathrm{H}]^{+}, \mathrm{C}_{30} \mathrm{H}_{42} \mathrm{~N}_{5} \mathrm{O}_{7}^{+}\right.$calcd 584.3). HRMS $m / z 584.3079\left([\mathrm{M}+\mathrm{H}]^{+}, \mathrm{C}_{30} \mathrm{H}_{42} \mathrm{~N}_{5} \mathrm{O}_{7}^{+}\right.$calcd 584.3079).

\section{ASSOCIATED CONTENT}

\section{Supporting Information}

Additional figures, additional experimental details, and compound characterization data, as well as ${ }^{1} \mathrm{H},{ }^{13} \mathrm{C}$, and ${ }^{19} \mathrm{~F}$ NMR spectra. This material is available free of charge via the Internet at http://pubs.acs.org.

\section{AUTHOR INFORMATION}

\section{Corresponding Author}

*Phone: +45 45252105. E-mail: cao@kemi.dtu.dk.

\section{Notes}

The authors declare no competing financial interest.

\section{ACKNOWLEDGMENTS}

Financial support from the Lundbeck Foundation (Young Group Leader Fellowship), the Danish Independent Research Council-Natural Sciences (Steno Grant No. 10-080907), and the Carlsberg Foundation is gratefully acknowledged.

\section{ABBREVIATIONS USED}

ADPR, adenosine diphosphate ribose; AMC, 7-amino-4methylcoumarin; DIC, N,N'-diisopropylcarbodiimide; H3, histone 3 protein; $\mathrm{H} 4$, histone 4 protein; HATU, O-(7azabenzotriazol-1-yl)- $N, N, N^{\prime}, N^{\prime}$-tetramethyluronium hexafluorophosphate; HDAC, histone deacetylase; HOBt, hydroxybenzotriazole; HPLC, high performance liquid chromatography; h, hour; KDAC, lysine deacylase; Kac, $\varepsilon$ - $N$-acetyllysine; Ksuc, $\varepsilon-N$ succinyllysine; Kma, $\varepsilon$ - $N$-malonyllysine; Ktfa, $\varepsilon$ - $N$-trifluoroacetyllysine; Kcr, $\varepsilon-N$-crotonyllysine; Ma, malonyl; MS, mass spectrometry; NAD, nicotinamide adenine dinucleotide; NMR, nuclear magnetic resonance; RFU, relative fluorescence unit; rt, room temperature; SIRT, sirtuin; Suc, succinyl; TFA, trifluoroacetic acid; $t_{\mathrm{R}}$, retention time; UPLC, ultrahigh performance liquid chromatography 


\section{REFERENCES}

(1) Biel, M.; Wascholowski, V.; Giannis, A. Epigenetics-an epicenter of gene regulation: histones and histone-modifying enzymes. Angew. Chem., Int. Ed. 2005, 44, 3186-3216.

(2) Schemies, J.; Uciechowska, U.; Sippl, W.; Jung, M. NAD ${ }^{+}$ dependent histone deacetylases (sirtuins) as novel therapeutic targets. Med. Res. Rev. 2010, 30, 861-889.

(3) Denu, J. M. The Sir2 family of protein deacetylases. Curr. Opin. Chem. Biol. 2005, 9, 431-440.

(4) Cole, P. A. Chemical probes for histone-modifying enzymes. Nat. Chem. Biol. 2008, 4, 590-597.

(5) Haigis, M. C.; Sinclair, D. A. Mammalian sirtuins: biological insights and disease relevance. Annu. Rev. Pathol.: Mech. Dis. 2010, 5, 253-295.

(6) Herranz, D.; Serrano, M. SIRT1: recent lessons from mouse models. Nat. Rev. Cancer 2010, 10, 819-823.

(7) Blum, C. A.; Ellis, J. L.; Loh, C.; Ng, P.-Y.; Perni, R. B.; Stein, R. L. SIRT1 modulation as a novel approach to the treatment of diseases of aging. J. Med. Chem. 2011, 54, 417-432.

(8) Milne, J. C.; Denu, J. M. The Sirtuin family: therapeutic targets to treat diseases of aging. Curr. Opin. Chem. Biol. 2008, 12, 11-17.

(9) Jackson, M. D.; Schmidt, M. T.; Oppenheimer, N. J.; Denu, J. M. Mechanism of nicotinamide inhibition and transglycosidation by Sir2 histone/protein deacetylases. J. Biol. Chem. 2003, 278, 50985-50998.

(10) Smith, B. C.; Denu, J. M. Acetyl-lysine analog peptides as mechanistic probes of protein deacetylases. J. Biol. Chem. 2007, 282, 37256-37265.

(11) Smith, B. C.; Hallows, W. C.; Denu, J. M. Mechanisms and molecular probes of sirtuins. Chem. Biol. 2008, 15, 1002-1013.

(12) Cen, Y.; Sauve, A. A. Transition state of ADP-ribosylation of acetyllysine catalyzed by Archaeoglobus fulgidus Sir2 determined by kinetic isotope effects and computational approaches. J. Am. Chem. Soc. 2010, 132, 12286-12298.

(13) Finnin, M. S.; Donigian, J. R.; Pavletich, N. P. Structure of the histone deacetylase SIRT2. Nat. Struct. Biol. 2001, 8, 621-625.

(14) Schuetz, A.; Min, J.; Antoshenko, T.; Wang, C. L.; AllaliHassani, A.; Dong, A.; Loppnau, P.; Vedadi, M.; Bochkarev, A.; Sternglanz, R.; Plotnikov, A. N. Structural basis of inhibition of the human $\mathrm{NAD}^{+}$-dependent deacetylase SIRT5 by suramin. Structure 2007, 15, 377-389.

(15) Jin, L.; Wei, W.; Jiang, Y.; Peng, H.; Cai, J.; Mao, C.; Dai, H.; Choy, W.; Bemis, J. E.; Jirousek, M. R.; Milne, J. C.; Westphal, C. H.; Perni, R. B. Crystal structures of human SIRT3 displaying substrateinduced conformational changes. J. Biol. Chem. 2009, 284, 2439424405.

(16) Min, J.; Landry, J.; Sternglanz, R.; Xu, R. M. Crystal structure of a SIR2 homolog-NAD complex. Cell 2001, 105, 269-279.

(17) Avalos, J. L.; Celic, I.; Muhammad, S.; Cosgrove, M. S.; Boeke, J. D.; Wolberger, C. Structure of a Sir2 enzyme bound to an acetylated p53 peptide. Mol. Cell 2002, 10, 523-535.

(18) North, B. J.; Marshall, B. L.; Borra, M. T.; Denu, J. M.; Verdin, E. The human Sir2 ortholog, SIRT2, is an $\mathrm{NAD}^{+}$-dependent tubulin deacetylase. Mol. Cell 2003, 11, 437-444.

(19) Blander, G.; Guarente, L. The Sir2 family of protein deacetylases. Annu. Rev. Biochem. 2004, 73, 417-435.

(20) Haigis, M. C.; Mostoslavsky, R.; Haigis, K. M.; Fahie, K.; Christodoulou, D. C.; Murphy, A. J.; Valenzuela, D. M.; Yancopoulos, G. D.; Karow, M.; Blander, G.; Wolberger, C.; Prolla, T. A.; Weindruch, R.; Alt, F. W.; Guarente, L. SIRT4 inhibits glutamate dehydrogenase and opposes the effects of calorie restriction in pancreatic beta cells. Cell 2006, 126, 941-954.

(21) Du, J.; Zhou, Y.; Su, X.; Yu, J. J.; Khan, S.; Jiang, H.; Kim, J.; Woo, J.; Kim, J. H.; Choi, B. H.; He, B.; Chen, W.; Zhang, S.; Cerione, R. A.; Auwerx, J.; Hao, Q.; Lin, H. Sirt5 is a NAD-dependent protein lysine demalonylase and desuccinylase. Science 2011, 334, 806-809.

(22) Olsen, C. A. Expansion of the lysine acylation landscape. Angew. Chem., Int. Ed. 2012, 51, 3755-3756.

(23) Michishita, E.; McCord, R. A.; Berber, E.; Kioi, M.; PadillaNash, H.; Damian, M.; Cheung, P.; Kusumoto, R.; Kawahara, T. L. A.;
Barrett, J. C.; Chang, H. Y.; Bohr, V. A.; Ried, T.; Gozani, O.; Chua, K. F. SIRT6 is a histone $\mathrm{H} 3$ lysine 9 deacetylase that modulates telomeric chromatin. Nature 2008, 452, 492-496.

(24) Bradner, J. E.; West, N.; Grachan, M. L.; Greenberg, E. F.; Haggarty, S. J.; Warnow, T.; Mazitschek, R. Chemical phylogenetics of histone deacetylases. Nat. Chem. Biol. 2010, 6, 238-243.

(25) Tan, M.; Luo, H.; Lee, S.; Jin, F.; Yang, J. S.; Montellier, E.; Buchou, T.; Cheng, Z.; Rousseaux, S.; Rajagopal, N.; Lu, Z.; Ye, Z.; Zhu, Q.; Wysocka, J.; Ye, Y.; Khochbin, S.; Ren, B.; Zhao, Y. Identification of 67 histone marks and histone lysine crotonylation as a new type of histone modification. Cell 2011, 146, 1016-1028.

(26) Heltweg, B.; Dequiedt, F.; Marshall, B. L.; Brauch, C.; Yoshida, M.; Nishino, N.; Verdin, E.; Jung, M. Subtype selective substrates for histone deacetylases. J. Med. Chem. 2004, 47, 5235-5243.

(27) He, B.; Du, J.; Lin, H. Thiosuccinyl peptides as SIRT5-specific inhibitors. J. Am. Chem. Soc. 2012, 134, 1922-1925.

(28) Vaziri, H.; Dessain, S. K.; Ng Eaton, E.; Imai, S. I.; Frye, R. A.; Pandita, T. K.; Guarente, L.; Weinberg, R. A. hSIR2(SIRT1) functions as an NAD-dependent p53 deacetylase. Cell 2001, 107, 149-159.

(29) Solomon, J. M.; Pasupuleti, R.; Xu, L.; McDonagh, T.; Curtis, R; DiStefano, P. S.; Huber, L. J. Inhibition of SIRT1 catalytic activity increases p53 acetylation but does not alter cell survival following DNA damage. Mol. Cell. Biol. 2006, 26, 28-38.

(30) Smith, B. C.; Denu, J. M. Mechanism-based inhibition of Sir2 deacetylases by thioacetyl-lysine peptide. Biochemistry 2007, 46, 14478-14486.

(31) While the present work was in progress, a patent application [WO2012006391 (2A), 2012] was published by Lin, H. Although, similar fluorogenic succinyllysine-containing substrates were mentioned in that patent application, optimized conditions with respect to enzyme loading and the secondary developer enzyme for continuous mechanistic assays were not dealt with. Furthermore, the minimal requirements of the peptide composition of the substrate were not investigated; thus, the substrates reported in this work are considerably more readily available by chemical synthesis.

(32) Xu, C.; Soragni, E.; Chou, C. J.; Herman, D.; Plasterer, H. L.; Rusche, J. R.; Gottesfeld, J. M. Chemical probes identify a role for histone deacetylase 3 in Friederich's Ataxia gene silencing. Chem. Biol. 2009, 16, 980-989.

(33) (a) Chou, C. J.; Herman, D.; Gottesfeld, J. M. Pimelic diphenylamide 106 is a slow, tight-binding inhibitor of class I histone deacetylases. J. Biol. Chem. 2008, 283, 35402-35409. (b) Vickers, C. J.; Olsen, C. A.; Leman, L. J.; Ghadiri, M. R. Discovery of HDAC inhibitors that lack an active site $\mathrm{Zn}^{2+}$-binding functional group, ACS Med. Chem. Lett. [Online early access]. DOI: $10.1021 / \mathrm{ml} 300081 \mathrm{u}$. Published Online: Apr 26, 2012.

(34) Grozinger, C. M.; Chao, E. D.; Blackwell, H. E.; Moazed, D.; Schreiber, S. L. Identification of a class of small molecule inhibitors of the sirtuin family of NAD-dependent deacetylases by phenotypic screening. J. Biol. Chem. 2001, 276, 38837-38843.

(35) Outeiro, T. F.; Kontopoulos, E.; Altmann, S. M.; Kufareva, I.; Strathearn, K. E.; Amore, A. M.; Volk, C. B.; Maxwell, M. M.; Rochet, J. C.; McLean, P. J.; Young, A. B.; Abagyan, R.; Feany, M. B.; Hyman, B. T.; Kazantsev, A. G. Sirtuin 2 inhibitors rescue alpha-synucleinmediated toxicity in models of Parkinson's disease. Science 2007, 317, $516-519$.

(36) Trapp, J.; Meier, R.; Hongwiset, D.; Kassack, M. U.; Sippl, W.; Jung, M. Structure-activity studies on suramin analogues as inhibitors of $\mathrm{NAD}^{+}$-dependent histone deacetylases (sirtuins). ChemMedChem 2007, 2, 1419-1431.

(37) Fatkins David, G.; Monnot Andrew, D.; Zheng, W. N-epsilonThioacetyl-lysine: a multi-facet functional probe for enzymatic protein lysine N-epsilon-deacetylation. Bioorg. Med. Chem. Lett. 2006, 16, 3651-3656.

(38) Huhtiniemi, T.; Salo, H. S.; Suuronen, T.; Poso, A.; Salminen, A.; Leppanen, J.; Jarho, E.; Lahtela-Kakkonen, M. Structure-based design of pseudopeptidic inhibitors for SIRT1 and SIRT2. J. Med. Chem. 2011, 54, 6456-6468. 
(39) Borra, M. T.; Smith, B. C.; Denu, J. M. Mechanism of human SIRT1 activation by resveratrol. J. Biol. Chem. 2005, 280, 1718717195 .

(40) Kaeberlein, M.; McDonagh, T.; Heltweg, B.; Hixon, J.; Westman, E. A.; Caldwell, S. D.; Napper, A.; Curtis, R.; DiStefano, P. S.; Fields, S.; Bedalov, A.; Kennedy, B. K. Substrate-specific activation of sirtuins by resveratrol. J. Biol. Chem. 2005, 280, 1703817045 .

(41) Beher, D.; Wu, J.; Cumine, S.; Kim, K. W.; Lu, S. C.; Atangan, L.; Wang, M. Resveratrol is not a direct activator of SIRT1 enzyme activity. Chem. Biol. Drug Des. 2009, 74, 619-624.

(42) Pacholec, M.; Bleasdale, J. E.; Chrunyk, B.; Cunningham, D.; Flynn, D.; Garofalo, R. S.; Griffith, D.; Griffor, M.; Loulakis, P.; Pabst, B.; Qiu, X.; Stockman, B.; Thanabal, V.; Varghese, A.; Ward, J.; Withka, J.; Ahn, K. SRT1720, SRT2183, SRT1460, and resveratrol are not direct activators of SIRT1. J. Biol, Chem. 2010, 285, 8340-8351.

(43) Lineweaver, H.; Burk, D. The determination of enzyme dissociation constants. J. Am. Chem. Soc. 1934, 56, 658-666.

(44) Tornheim, K. Kinetic applications using high substrate and competitive inhibitor concentrations to determine $K_{\mathrm{i}}$ or $K_{\mathrm{m}}$. Anal. Biochem. 1994, 221, 53-56.

(45) Wegener, D.; Wirsching, F.; Riester, D.; Schweinhorst, A. A fluorogenic histone deacetylase assay well suited for high-throughput activity screening. Chem. Biol. 2003, 10, 61-68. 